\title{
Global research priorities for sea turtles: informing management and conservation in the 21st century
}

\author{
M. Hamann ${ }^{1}$, M. H. Godfrey ${ }^{2}$, J. A. Seminoff ${ }^{3}$, K. Arthur ${ }^{4}$, P. C. R. Barata ${ }^{\text {, }}$ \\ K. A. Bjorndal ${ }^{6}$, A. B. Bolten ${ }^{6}$, A. C. Broderick ${ }^{7}$, L. M. Campbell ${ }^{8}$, C. Carreras $^{9}$, \\ P. Casale ${ }^{10}$, M. Chaloupka ${ }^{11}$, S. K. F. Chan ${ }^{12}$, M. S. Coyne ${ }^{7}$, ${ }^{13}$, L. B. Crowder ${ }^{8}$, \\ C. E. Diez ${ }^{14}$, P. H. Dutton ${ }^{3}$, S. P. Epperly ${ }^{15}$, N. N. FitzSimmons ${ }^{16}$, A. Formia ${ }^{17}$,
} M. Girondot ${ }^{18}$, G. C. Hays ${ }^{19}$, I. J. Cheng ${ }^{20}$, Y. Kaska ${ }^{21}$, R. Lewison ${ }^{22}$, J. A. Mortimer ${ }^{23}$, W. J. Nichols ${ }^{24}$, R. D. Reina ${ }^{25}$, K. Shanker ${ }^{26}$, J. R. $\operatorname{Spotila}^{27}$, J. Tomás ${ }^{28}$, B. P. Wallace ${ }^{29,30}$, T. M. Work ${ }^{31}$, J. Zbinden ${ }^{32}$, B. J. Godley ${ }^{7, *}$

${ }^{1}$ School of Earth and Environmental Sciences, James Cook University, Townsville, Queensland 4811, Australia

${ }^{7}$ Marine turtle Research Group, Centre for Ecology and Conservation, School of Biosciences, University of Exeter, Tremough Campus, Treliever Road, Penryn, Cornwall TR10 9EZ, UK

\begin{abstract}
Over the past 3 decades, the status of sea turtles and the need for their protection to aid population recovery have increasingly captured the interest of government agencies, non-governmental organisations (NGOs) and the general public worldwide. This interest has been matched by increased research attention, focusing on a wide variety of topics relating to sea turtle biology and ecology, together with the interrelations of sea turtles with the physical and natural environments. Although sea turtles have been better studied than most other marine fauna, management actions and their evaluation are often hindered by the lack of data on turtle biology, human-turtle interactions, turtle population status and threats. In an effort to inform effective sea turtle conservation a list of priority research questions was assembled based on the opinions of 35 sea turtle researchers from 13 nations working in fields related to turtle biology and/or conservation. The combined experience of the contributing researchers spanned the globe as well as many relevant disciplines involved in conservation research. An initial list of more than 200 questions gathered from respondents was condensed into 20 metaquestions and classified under 5 categories: reproductive biology, biogeography, population ecology, threats and conservation strategies.
\end{abstract}

KEY WORDS: Sea turtles $\cdot$ Global priorities $\cdot$ Research $\cdot$ Conservation

Resale or republication not permitted without written consent of the publisher

\section{INTRODUCTION}

Over the past 30 years, the status of sea turtles and the need for their protection and population recovery have increasingly captured the interest of many government agencies, non-governmental organisations (NGOs) and the general public (Raustiala 1997, Wright \& Mohanty 2006, Campbell 2007). This interest has been matched with increased research attention, which focuses on a wide variety of topics relating to sea turtle biology and conservation, including the interrelations with the physical and biological environ- ments in which they live, and the human dimensions associated with these elements (Avise 2007, Campbell \& Cornwell 2008). Indeed, for the last 3 decades there has been an annual symposium dedicated to sea turtle biology and conservation; recently the symposium has had roughly 300 presentations annually, with attendees from over 80 countries across 6 continents (see www.seaturtlesociety.org). The growing body of peerreviewed literature has equally reflected the increase in sea turtle research, with the ISI Web of Science reporting 813 research items from 2006 to 2009 in a search for 'sea turtle' or 'marine turtle' and 'conserva- 
tion'. However, despite being well studied in comparison to many other marine fauna, management actions and their evaluation for sea turtles are still frequently hindered by lack of key data on turtle biology, human-turtle interactions, turtle population status and environmental threats (e.g. Bjorndal 1999, Amorocho 2002).

Given the heightened interest in sea turtle research, monitoring and management, it is timely to seek opinion from researchers about the most important research questions in order to assist sea turtle conservation. Thus, in a similar fashion to Sutherland et al. (2006, 2009), the opinions of researchers working in fields related to sea turtle biology, conservation and/or their management were assembled into a list of 20 priority questions (Box 1) that can be used to guide future research efforts. This is by no means the first attempt to collate and prioritise pertinent research questions to assist sea turtle conservation, as similar efforts at local, regional and international scales have occurred (IUCN 1995, Bellagio Steering Committee 2004, Mast et al. 2004, 2005, 2006, CPPS 2006). However, several of the early efforts that developed priority research themes were valuable at the time, but were too focused on species or regions, and many are now out of date, especially given the surge in published research, technological advances and the evolving challenges facing sea turtle conservation. The present paper reflects the ideas from an unprecedented collection of researchers from a broad range of backgrounds, and is the first such effort to detail the most relevant conservationinformative research questions in the published literature with regard to sea turtles. Through the listing process we aim to move research and management forward by focusing effort and expertise on what are communally held as priority research questions for sea turtle conservation.

\section{METHODS}

Four of the authors of this paper (M.H., B.J.G., M.H.G. and J.A.S.) initiated the study. On ISI Web of Knowledge we searched the years 2006 to 2009 for '(SEA TURTLE or MARINE TURTLE) and CONSERVATION' (accessed 4 April 2009). We analyzed the resulting output (813 papers) by author. Among the authors of these papers, 131 had published more than 3 relevant studies over the period. To maximise the geographic/technical experience of panel members, each of the 4 initiating authors independently selected 20 authors from this list, with a key aim being to maximise representation. These names were combined into a new list and those selected by more than 2 of the initiating authors were invited to contribute $(\mathrm{n}=40)$.
Box 1. Five priority research categories comprising 20 metaquestions relating to sea turtle research and conservation

\section{Reproductive biology}

1.1. What are the factors that underpin nest site selection and behaviour of nesting turtles?

1.2. What are the primary sex ratios being produced and how do these vary within or among populations and species?

1.3. What factors are important for sustained hatchling production?

\section{Biogeography}

2.1. What are the population boundaries and connections that exist among rookeries and foraging grounds?

2.2. What parameters influence the biogeography of sea turtles in the oceanic realm?

2.3. Where are key foraging habitats?

3. Population ecology

3.1. Can we develop methods to accurately age individual turtles, determine a population's (or species') mean ageat-maturity, and define age-based demography?

3.2. What are the most reliable methods for estimating demographic parameters?

3.3. How can we develop an understanding of sea turtle metapopulation dynamics and conservation biogeography?

3.4. What are the past and present roles of sea turtles in the ecosystem?

3.5. What constitutes a healthy turtle?

\section{Threats}

4.1. What will be the impacts from climate change on sea turtles and how can these be mitigated?

4.2. What are the major sources of fisheries bycatch and how can these be mitigated in ways that are ecologically, economically and socially practicable?

4.3. How can we evaluate the effects of anthropogenic factors on sea turtle habitats?

4.4. What are the impacts of pollution on sea turtles and their habitats?

4.5. What are the etiology and epidemiology of fibropapillomatosis (FP), and how can this disease be managed?

5. Conservation strategies

5.1. How can we effectively determine the conservation status of sea turtle populations?

5.2. What are the most viable cultural, legal and socioeconomic frameworks for sea turtle conservation?

5.3. Which conservation strategies are working (have worked) and which have failed?

5.4. Under what conditions (ecological, environmental, social and political) can consumptive use of sea turtles be sustained?

A total of 35 researchers contributed to this effort, with each proposing up to 10 ranked 'research questions to assist effective sea turtle conservation over the next 10 years'. Responses were 'blind', as questions and compilations were not shared with the wider group until all questions had been submitted.

The 35 participants (10 females and 25 males) are based in 13 countries representing experience in all oceanic basins where sea turtles exist (Eastern Pacific $12 \%$, Central Pacific 9\%, Western Pacific 11\%, East- 
ern Atlantic (including Mediterranean) 17\%, Central Atlantic 13\%, Western Atlantic 21\%, Indian Ocean $7 \%$ and Southern Ocean 10\%). Participants contributed a mean of 8.5 research questions $(\mathrm{SD}=2.1$, range $=4$ to 10 ), producing a total of 347 questions. M.H., B.J.G., M.H.G. and J.A.S. grouped the questions first into themes/subthemes $(n=14 / 46)$ and then into 23 metaquestions. The wording of each metaquestion was based on the most common ideas that occurred in individual questions. In most cases, a submitted question clearly fell into a single theme; with questions that bridged 2 or more themes, a best effort was made to determine the dominant theme of the question where it was then placed. After compilation into thematic groupings, the final list of metaquestions was circulated to all 35 participants for consensus, and the final 20 questions were selected.

After reaching consensus, teams of 2 or 3 authors drafted the supporting text for the description of each metaquestion. These topical descriptions were written with a focus on those most commonly occurring ideas within each theme while also trying to capture all ideas presented by individual questions. For ease of reporting, the 20 metaquestions were organised into 5 categories after consultation with coauthors (Box 1): (1) reproductive biology, (2) biogeography, (3) population ecology, (4) threats, and (5) conservation strategies. The text of the sections discussed in 'Results' has been left as close as possible to the original provided by the author groups. Metaquestions are not ranked or listed relative to each other in terms of importance.

\section{RESULTS}

\section{Reproductive biology}

This category focuses on research questions related to sea turtles at the nesting beach. Because hatchling production relies on sea turtles laying clutches of eggs in a section of beach above the mean high tide line and because embryo development and phenotype are strongly linked to sand temperatures, beach ecosystems are a critical component of sea turtle lifecycles.

\subsection{What are the factors that underpin nest site selection and behaviour of nesting turtles?}

Although the minimum criteria for habitat that is suitable for nesting and hatchling production were laid out nearly 2 decades ago (Mortimer 1990), the underpinnings of nest site selection by sea turtles largely remain a mystery. The related questions submitted were linked to breeding behaviour of both adult male and female turtles, with an emphasis on (1) the precision of natal homing, (2) the factors (biotic and abiotic) driving where and when turtles lay their clutches, and (3) what management strategies would help protect or enhance the suitability of nesting habitat for sea turtles. Although natal homing behaviour in both male and female turtles is supported by genetic analyses for nearly all species (Meylan et al. 1990, FitzSimmons et al. 1997), studies have highlighted the flexibility of this behaviour among and within species (Dutton et al. 1999, Shanker et al. 2004, Hilterman \& Goverse 2007). Improving our understanding of the level of plasticity in natal homing (see Section 2.1) would assist management, particularly within the context of adaptation and resilience to global climate change and/or coastal development (see Section 4.1), and the possible spatio-temporal changes in availability of suitable nesting habitats for sea turtles (Hamann et al. 2007a, Hawkes et al. 2009). For nest site selection, past studies have indicated that species tend to prefer specific zones of the beach (e.g. Whitmore \& Dutton 1985, Hays et al. 1995, Dobbs et al. 1999), although more is known about what specific cues deter nesting than those that encourage it (Miller et al. 2003). Recent studies suggest that individual turtles tend to repeatedly nest at specific sites, although overall nest location may vary across a population (Kamel \& Mrosovsky 2004, 2005) and there is likely to be species- and region-specific variation in the magnitude of nest site fidelity (Pfaller et al. 2009). Manipulation of the nesting beach is linked to changes in patterns of placement of sea turtle nests (Salmon et al. 1995, Wetterer et al. 2007), but rarely are these changes linked to increased hatchling production. We need a better understanding of how nesting females respond to situations in which anthropogenic or natural factors render their beaches unsuitable for nesting, and in particular of the limits to their ability to locate an alternate nesting site. To date, management strategies to improve nesting habitat have focused on responding to perceived threats, such as control of nest predators (Engeman et al. 2005), removal of nonnative vegetation (Schmid et al. 2008), reduction of artificial lighting visible on the beach (Bertolotti \& Salmon 2005), and artificially widening beaches as part of erosion control (Montague 2008). Greater insight into why turtles breed successfully at specific beaches and also specific zones of the beach could lead to management strategies that maximise hatchling production in particular areas. Spatial models (Santana-Garcon et al. 2010) and experimental manipulations (Caut et al. 2006) appear likely routes towards attaining this goal. 
1.2. What are the primary sex ratios being produced and how do these vary within or among populations and species?

All species of sea turtle have temperature-dependent sex determination (TSD), with female offspring produced at higher temperatures (Yntema \& Mrosovsky 1980). Reviews of the peer-reviewed literature (Wibbels 2003, Hawkes et al. 2009) have summarised studies on sex ratios of hatchling sea turtles; most have reported female-biased sex ratios. The latest review highlighted that overall, relatively few robust datasets on hatchling sex ratios are available that are not laboratory based or based on proxies such as sand temperature or incubation duration (Hawkes et al. 2009). A major reason for the paucity of data is that the only reliable method of sexing hatchlings currently available is histological examination of the gonads from dead hatchlings. Given that most sea turtle species are of conservation concern, studies requiring euthanasia are often hard to justify on an ethical basis, and as a result are generally based on a small number of hatchlings (Mrosovsky et al. 2002), or in the case of sampling from naturally dead hatchlings, there are issues with sample size and biased results (Broderick et al. 2000). As an alternative, studies have focused on estimating hatchling sex ratios from sand temperature (Glen \& Mrosovsky 2004, Hawkes et al. 2007), clutch temperature (Godley et al. 2001), incubation duration (driven by temperature; Marcovaldi et al. 1997, Zbinden et al. 2007) and by analysing hormone levels from amniotic fluids (Gross et al. 1995). A recent advance has been the adaptation of surgical laparoscopy to determine sex of post-hatchling turtles (2.5 to 6 mo old; Wyneken et al. 2007). Although there are technical and logistic challenges associated with it, the method has been applied to a variety of species, and data from loggerheads have been used in population models (Wyneken et al. 2003). Therefore, continuing to develop and refine methods to reliably and non-lethally sex hatchlings is crucial to further elucidate the variation that exists and to allow an assessment of the capacity for adaptation to climate change (see Section 4.1). A more indirect approach to assessing sex ratio is to evaluate the juvenile-through-subadult portion of the population on the assumption that it represents a condensation of many years of hatchling production. This can be done by capturing turtles at their foraging habitats and determining sex by using laparoscopy (Limpus et al. 1994), sex steroid concentrations (Owens et al. 1978) and possibly ultrasound (Blanvillain et al. 2008). Whether or not sex ratios persist through age classes is likely to vary within and between species, and while data on hatchling sex ratios are limited, there are even fewer data on sex ratios in other age classes for most species and populations (Limpus 2008a, Conant et al. 2009). If there is excessive feminisation of hatchling sex ratios brought about by climate change, this may result in reduced fertility rates (but see Bell et al. 2009) or, through random drift and loss of genetic variation, compromise a population's ability to respond to selection pressures. As a result, it may be necessary to investigate the development and implementation of mitigation methods to reduce negative impacts in some populations (but see Girondot et al. 1998). Current suggested mitigation techniques include increasing shade on beaches or relocating clutches to sites with cooler temperatures, either within a beach, or at new sites. Pros and cons of these techniques are likely to vary within and among species and locations. Another area worthy of future investigation is to identify new nesting areas, particularly if current nesting sites become unsuitable due to development or climate-driven change (Hamann et al. 2007a, Poloczanska et al. 2009). Identifying these new sites however requires an adequate understanding of factors that are important for nest site selection (see Section 1.1) as well as of factors that determine embryonic development, sex, hatchling dispersal and plasticity of natal homing.

\subsection{What factors are important for sustained hatchling production?}

Improving knowledge of embryology and hatchling production is a fundamental component of nesting beach management. Knowledge of embryology is needed to improve understanding of hatchling fitness and phenotype, which will become more important with climate change (see Section 4.1). Hatchling production is important because it is a fundamental component of population models (see Section 3.3). Although hatchling production has been a popular area of research over the last 4 decades (Miller 1985, Standora \& Spotila 1985, Ackerman 1997), a substantial proportion of research to date has focused on aspects of sex determination (see Section 1.2), and many research and monitoring gaps remain. For example, continued collection of population-scale data on hatching success, fertility rates, egg predation and sex ratios is needed to understand variation in hatchling production. Key areas for future study include embryology (Bell et al. 2004), experimental studies that elucidate environmental effects, including pollutants (see Section 4.4), on embryology, physiology and endocrinology of developing eggs and hatchlings (Hamann et al. 2007b, Booth 2009), developing and evaluating a reliable estimate of hatchling fitness, understanding endocrine influences on embryology, and furthering investigations on nest site selection (see Section 1.1) and its 
role in hatchling production. Continuing research into these topics will enhance the ability of scientists and managers to better understand the adaptive capacity and resilience of sea turtles to climate change (see Section 4.1) and coastal zone development (see Sections 4.3 and 4.4) and to better model and manage directed and incidental take.

\section{Biogeography}

Sea turtles are migratory, often travelling great distances between natal beaches and foraging areas, and/or between foraging areas and reproductive sites. Recent technological advances in genetics, telemetry, remote sensing, and biochemical markers are increasing our knowledge of the distribution and behaviour of sea turtles in offshore waters, although many information gaps remain.

\subsection{What are the population boundaries and connections that exist among rookeries and foraging grounds?}

For many years, sea turtle researchers have recognised the primary importance of defining appropriate 'management units' (MUs). MUs are population segments that exhibit unique demography and can usually be distinguished genetically, behaviourally, or geographically (Moritz 1994) and are the units to which conservation efforts should be directed. Because sea turtles occupy broad geographic ranges including nesting and foraging areas utilised by adults, and in some cases geographically distinct ontogenetic habitats (Musick \& Limpus 1997), defining the scale of MUs is challenging. Furthermore, sea turtles exhibit complex population structures often characterised by sex-biased gene flow among nesting stocks, and varying degrees of overlap during post-hatchling migrations, in developmental habitats, and on adult foraging grounds (see Bowen \& Karl 2007 for review). Knowledge of the complex relationships among various nesting sites and foraging/nursery areas is crucial for understanding population-level impacts of anthropogenic threats, as well as for designing effective conservation responses to these threats (Bolker et al. 2007). Despite the challenges of collecting data, tremendous advances have been achieved over the past 2 decades to characterise MUs at various spatial scales. A variety of tools including genetic analyses with mitochondrial and nuclear markers (mtDNA sequences, microsatellite polymorphisms, and single nucleotide polymorphisms [SNPs]), mark-recapture studies, and satellite telemetry have permitted determination of nesting and breeding genetic stocks, of mixed genetic stocks on foraging grounds, and of geographic distributions of sea turtle populations around the world (Meylan et al. 1990, FitzSimmons et al. 1997, Polovina et al. 2004, Carreras et al. 2006, Dethmers et al. 2006, Dutton et al. 2008, Godley et al. 2008). Integration of these tools, especially when supplemented with information on the spatial extent and severity of threats plus oceanography and environmental drivers, holds exciting potential for successfully defining MUs for sea turtles globally, thereby facilitating design and implementation of effective, targeted, conservation strategies.

\subsection{What parameters influence the biogeography of sea turtles in the oceanic realm?}

Questions in this section were divided into the following general topics: (1) geographic location of the oceanic 'hotspots', whether they be migratory pathways or foraging areas; (2) demography of turtles in the oceanic stages, including the duration of oceanic juvenile stages and the cues for turtles to leave the oceanic zone; and (3) physical and biological oceanographic factors driving sea turtle distribution patterns. The oceanic zone, where water depths are greater than $200 \mathrm{~m}$, is a developmental habitat for all species of sea turtles except flatback turtles and is also an adult foraging habitat for leatherback, olive ridley and loggerhead turtles (Hatase et al. 2002a, Bolten 2003, Hawkes et al. 2006, Reich et al. 2007, 2010). The classic paper by Carr (1986) introduced the importance of the oceanic zone as a developmental habitat. Movements of turtles into and out of the oceanic zone are primarily the result of ontogenetic migrations (Bowen et al.1995, Bolten et al. 1998, Boyle et al. 2009, Monzón-Argüello et al. 2009) or reproductive migrations (Hays et al. 2001, James et al. 2005a, Benson et al. $2007 a, b)$. However, recent studies using stable isotope analyses and satellite telemetry suggest that there may be repeated movements between neritic and oceanic habitats (Hatase et al. 2002a,b, Hawkes et al. 2006, McClellan \& Read 2007). Demographic parameters derived from empirical studies for oceanic juvenile sea turtles come primarily from loggerhead turtles in the North Atlantic (Bjorndal et al. 2000, 2003a,b, Sasso \& Epperly 2007). Bolten (2003) suggested that the selective advantage of ontogenetic habitat shifts from oceanic to neritic zones for juvenile loggerhead turtles may be a maximisation of growth rates. Some oceanic hotspots for sea turtles, particularly juvenile stages, have been identified, and these include sites in the northeast Atlantic (Carr 1986, Bolten et al. 1993), northwest Atlantic/Grand Banks of Canada (Witzell 1999), Mediterranean (Aguilar et al. 1995, Casale 
2008), southwest Atlantic/Rio Grande Rise (Sales et al. 2008), North Central Pacific (Wetherall et al. 1993, Balazs \& Pooley 1994), southeast Pacific (Alfaro Shigueto et al. 2008) and eastern Pacific (Peckham et al. 2007). Primary physical parameters influencing the spatial distribution of oceanic sea turtles are currents and associated fronts and eddies, bathymetry (particularly seamounts), sea surface temperature and magnetic field (Polovina et al. 2000, 2004, 2006, Lohmann \& Lohmann 2003, Luschi et al. 2003, Revelles et al. 2007, Santos et al. 2007, Kobayashi et al. 2008). Currents in particular are likely to influence neonatal dispersal. Biological parameters influencing spatial distribution include the distribution and abundance of prey (primarily gelatinous zooplankton) and possibly predators (Polovina et al. 2000, 2001, 2004, 2006, Hays et al. 2001, 2004, James et al. 2005b, Heithaus et al. 2008, Kobayashi et al. 2008). Anthropogenic disturbances to oceanic food webs and habitats may affect the distribution and abundance of sea turtles (Bjorndal 1997, Mrosovsky et al. 2009, Richardson et al. 2009). Fisheries bycatch, marine debris and pollution are important sources of mortality and may affect sea turtle distribution (Lewison \& Crowder 2007, Mrosovsky et al. 2009). Although we have learned much since Carr's (1986) paper, we have only just begun to understand the biology of the oceanic stages. We are a long way from our goal of developing predictive models of sea turtle distribution patterns in the oceanic zone.

\subsection{Where are key foraging habitats?}

Marine turtles spend the vast majority of their lives in the marine environment, yet much less is known about this component of their life cycle than about the biology of females and hatchlings on the nesting beach. One way to understand where turtles are feeding is to identify the migratory routes that turtles use to move between nesting and foraging areas. Within foraging habitats it is vital to understand what oceanographic and biological parameters determine the home range of a turtle, how the space is used, and what defines an 'optimum' foraging habitat. In addition, it is important to understand the degree of site fidelity to any given foraging area, especially seemingly 'sub-optimal' areas and where, when and why high density aggregations occur. Furthermore, the foraging areas for a given nesting population can be spread over many thousands of kilometers and little is known about why turtles show fidelity to foraging areas distant to a breeding area when presumably suitable foraging areas are often located close to breeding sites, or along migration routes. Current knowledge of turtle spatial ecology comes from tag-recapture studies, and more recently, satellite telemetry (Hendrickson 1958, Limpus et al. 1992, Plotkin 2003, Godley et al. 2008). However, to date, much of this knowledge is incomplete, with many of the above questions only being addressed for some species in a few regions. Future studies should look to incorporate multiple approaches to understand spatial ecology of sea turtles, including genetics (Bowen 1995), intrinsic biomarkers such as stable isotopes (Caut et al. 2008), ultrasonic or VHF radio tags (Seminoff et al. 2002), fisheries interactions (Witt et al. 2008), animal-borne imagery (Heithaus et al. 2002), and ocean current modelling (Godley et al. in press) as accompaniments to more conventional tracking methodologies. Understanding turtle spatial ecology and identifying critical foraging habitats, high and low density areas and migratory pathways is integral in sea turtle conservation and underpins all other facets of sea turtle research. In addition, because turtles travel vast distances and cross international boundaries (Limpus et al.1992, Nichols et al. 2000), their successful management benefits from multinational co-operation (Blumenthal et al. 2006, Shillinger et al. 2008).

\section{Population ecology}

Sea turtles are late maturing, migratory animals; hence, their life cycles tend to be complex. It has become clear that modelling life history and population dynamics of sea turtles requires information for several life stages, particularly those at sea.

3.1. Can we develop methods to accurately age individual turtles, determine a population's

(or species') mean age-at-maturity, and define age-based demography?

A fundamental aspect of sea turtle management and conservation is the use of population models as a basis for making decisions. Because it is imperative that models are based on sound science, there is a fundamental necessity for accurate data on factors such as age-at-maturity and age-based demographic parameters, as model outputs are sensitive to variations in these parameters (Heppell 1998, Heppell et al. 2000). Both age- and stage-based population models have been developed for sea turtles (Crouse et al. 1987, Chaloupka 2002, Heppell et al. 2005), although efforts to model survivorship are often hampered by our inability to accurately determine the age of live turtles. Still, such efforts require adequate distinction between demographic variability and sampling variability (Akçakaya 2000). In order to improve estimates of age, researchers have calculated both growth rates 
and/or age of sea turtles using skeletochronology (Zug et al. 1995, 2001, Snover 2002, Bjorndal et al. 2003b, Snover et al. 2007, Avens et al. 2009), capture-mark-recapture (Chaloupka \& Limpus 1997, Higgins et al. 1997, Limpus \& Chaloupka 1997, Braun-McNeill et al. 2008), and length frequency analyses (Bjorndal et al. 2000, 2001). The biases of each of these methods, as well as spatial and temporal variation in the results from each, are still being explored, and methods are being validated. However, there remains a paucity of information on age as it relates to life stage or mortality for many sea turtle populations and we have almost no measures of demographic stochasticity (Chaloupka 2002). In some areas, animals are monitored through their neritic stage to determine the length of time, and possibly age, to reproductive maturation (Limpus 2008a,b), but such studies are rare. In other cases hatchlings or small juveniles were marked and nesting beaches monitored for their return as adults - thus giving an age at first breeding (Zurita et al. 1994, Bell et al. 2007, Limpus 2008a,b); recent advances in genetic markers have the potential to provide this information (Dutton et al. 2005). New techniques to quantify or validate age estimates should greatly contribute to more powerful demographic analyses, e.g. monitoring radioactive decay rates (Andrews et al. 2009), and improved models will strengthen management decisions for the species.

3.2. What are the most reliable methods for estimating demographic parameters?

A number of submissions highlighted the need for reliable estimates of demographic parameters (e.g. clutch frequency, age-specific survivorship, male breeding rates) that could be fed into life history models. Questions fell into 2 broad groups. Approximately half dealt with the estimation of accurate parameter values for life history models, including mortality, and the rest were about the application of models. Several authors have attempted to estimate mortality in sea turtles (Chaloupka \& Limpus 2005, Troëng \& Chaloupka 2007) but existing models are still not capable of including all the current knowledge from life history stages. Also, improved knowledge of the distribution, variation and estimation of both clutch frequency (Broderick et al. 2003, Briane et al. 2007) and remigration interval (Hays 2000, Rivalan et al. 2005a, Tucker 2010), and technical aspects such as tag loss (Limpus 1992, Bjorndal et al. 1996, Rivalan et al. 2005b) are required for more accurate population models. Estimation of these parameters should be undertaken at the same time as estimation of capture probability and mortality, but no such model has been published. Estimates of juvenile, subadult, adult male, and non-breeding adult female mortality have not been adequately developed for most species/ locations. Analyses of stranding and other mortality data sets could be part of a solution, but knowledge is needed as to the true cause of death and the probability of a dead turtle being observed (Epperly et al. 1996). To improve life history models, information is needed on hatchling production, sex ratios and their associated spatial and temporal variation, and sex-specific mortality rates (see Sections 1.2 and 1.3). Another significant gap relates to the role of male turtles within the framework of functional (or operational or adult) sex ratio and how it affects the fertilisation probability or the intrasex competition (Lovich 1996).

3.3. How can we develop an understanding of sea turtle metapopulation dynamics and conservation biogeography?

Sea turtles pose many challenges for understanding population viability and biogeography because a management unit may comprise a single regional breeding area sourced from geographically scattered foraging habitats (Musick \& Limpus 1997; see Section 2.1). Demographic trends in foraging areas of the same population can vary significantly (Chaloupka \& Limpus 2001), mainly due to local factors affecting somatic growth (Balazs \& Chaloupka 2004, Chaloupka et al. 2004a; see Section 3.2). On the other hand, regional environmental forcing can cause spatially synchronised nesting of sea turtle populations by driving food supply dynamics in foraging habitats (Limpus \& Nicholls 1988, Chaloupka 2001, Chaloupka et al. 2008a). Importantly, dispersal among nesting sites could help locally depleted subpopulations recover more quickly by immigration from nearby subpopulations and minimise local extinction risk ('rescue effect'). Thus, incorporating spatial variation in demography and nesting fidelity is essential for developing an understanding of the viability of such spatially structured stocks (Akçakaya 2000). Spatially explicit models that account for the population structure are a promising way to address this challenge for sea turtle stocks (Chaloupka 2004). Such models may also be of use for the design and application of effective marine protected areas. However, spatially explicit population models are far more demanding in terms of level of detail for specific demographic inputs (Ruckelshaus et al. 1997), which to date has limited their use for modelling sea turtle dynamics (Chaloupka 2004). For instance, little is known of foraging habitat dispersal or whether dispersal probability is a function of distance between the source-sink populations or whether it is even due to source population abundance (Chaloupka 
2004). Nonetheless, developing spatially explicit models of sea turtle demography could provide a mechanistic basis for understanding the impact of climate change on sea turtle distribution (Keith et al. 2008) and the impact of direct and incidental take (see Sections 4.1, 4.2 and 4.3).

\subsection{What are the past and present roles of sea turtles in the ecosystem?}

For long-term conservation of sea turtles, it is important to acknowledge that they are not just charismatic, anachronistic animals, but vital species for healthy marine ecosystems. 'We envision marine turtles fulfilling their ecological roles on a healthy planet where all peoples value and celebrate their continued survival' is the vision of the IUCN Marine Turtle Specialist Group (MTSG) (www.iucn-mtsg.org/about.shtml). A recovery goal of 'fulfilling ecological roles' appropriately shifts the focus of management away from single-species recovery strategies to restoration of ecosystem function. Recent collapses of marine ecosystems, with dramatic shifts in food webs and trophic cascades, are the result of events both recent and initiated hundreds to thousands of years ago, soon after humans began to exploit marine resources (Jackson et al. 2001, Pitcher 2001, Frazier 2003, Pandolfi et al. 2003). 'Fulfilling ecological roles' is an appropriate, but challenging, goal for recovery. What were the ecological roles of sea turtles, and how many turtles are required to fulfil those roles? To answer these questions, we must combine a historical perspective with a thorough understanding of the current ecological roles of sea turtles. Quantitative models that combine results from observational and experimental studies with extrapolations to past population sizes are needed to reconstruct the roles of sea turtles in the past (Bjorndal \& Jackson 2003). We need more information at all levels, from individuals to populations to ecosystems (Bjorndal 2003). The most pressing needs, however, are for studies that address the major roles of sea turtles as ecosystem engineers (Rogers 1989, Preen 1996, León \& Bjorndal 2002, Moran \& Bjorndal 2005, 2007, Aragones et al. 2006), nutrient transporters (Bouchard \& Bjorndal 2000), consumers (Bjorndal 1997), and prey (Heithaus et al. 2007). Quantitative studies are needed; for example, we need to know how much turtles consume, not just what species (Bjorndal \& Jackson 2003). Long-term studies are needed that evaluate the responses of turtles to collapsing ecosystems, such as the disintegration of coral reefs killed by bleaching, or the eutrophication of coastal seagrass pastures. Areas where sea turtle populations have not been substantially impacted by humans or have begun to recover and resume their critical roles in marine ecosystems would be valuable study sites. These studies will reveal the importance of sea turtles to the productivity of marine ecosystems, and in turn, the importance to ecological services and economic benefits that marine ecosystems provide to humans (Costanza et al. 1997).

\subsection{What constitutes a healthy turtle?}

A number of research topics were highlighted that are grouped under this overarching question. These focused on (1) the need for normal baseline physiological (blood work) studies for different species and geographic regions, (2) determining the effects of disease on population viability, (3) elucidating the role of environmental factors in disease and how these will be affected by climate change, (4) developing a better understanding of parasite presence in, and health impacts on, sea turtles and (5) developing a better understanding of the health status of pelagic turtles. Baseline biochemistry and haematology information is available for several sea turtle species, including loggerheads (Lutz \& Dunbar-Cooper 1987, Casal \& Oros 2007), green turtles (Work et al. 1998), olive ridleys (Santoro \& Meneses 2007) and leatherbacks (Deem et al. 2006), although geographic, seasonal and life-stage variation in these values merit further investigation. Little is known about how these physiological parameters vary with health status, although progress is being made using immune function tests in relation to contaminant burdens in loggerheads (Keller et al. 2004) and fibropapillomatosis (FP) in green turtles (Work et al. 2001; see also Section 4.5). The determination of population effects of disease is hampered by lack of longterm disease data, one exception being the case study for FP in Hawaii (Chaloupka \& Balazs 2005, Chaloupka et al. 2009). Similarly, little is known regarding the effects of environment or climate change and disease in wild turtles, although it is known that certain diseases such as FP have non-uniform geographic distribution (Work et al. 2004, see Section 4.5). There is a considerable body of literature on parasites of sea turtles that focuses mainly on systematics (Greiner et al. 1980, Aznar et al. 1998) or host response to parasites (Gordon et al. 1998), while the demographics of parasites in sea turtles are less well understood (Work et al. 2005). Importantly, little is known about the health status of oceanic turtles - mainly because this life history stage is often difficult to study. Various strategies (each with inherent limitations) have been used to assess pelagic health, including capture of oceanic immature turtles (Bjorndal et al. 2003a), use of satellite telemetry (Chaloupka et al. 2004 b), or necropsy of animals subject to bycatch (Work \& Balazs 2002). Finally, a consensus is needed to delin- 
eate what constitutes animals suitably healthy for release after long-term captivity or rehabilitation. Ideally, this should be decided on a case by case basis, with emphasis on a sound health history of release stock, preferably including systematic post-mortem exams of all captive mortalities at the same facility to determine causes of death and thus to minimise risks of introducing new pathogens into release habitats.

\section{Threats}

Sea turtles face a wide variety of threats throughout their complex life histories. More information is needed to elucidate threats and also prioritise responses to such threats which will help drive more effective mitigation strategies.

4.1. What will be the impacts from climate change on sea turtles and how can these be mitigated?

A large number of questions relating to climate change were submitted. The foci of the questions were (1) illuminating what kinds of impacts climate change will have on habitats (developmental, foraging, nesting, etc.; see Section 4.3); (2) monitoring behavioural changes of turtles in response to those changes (see Section 1.1); (3) examining the adaptive capacity of turtles to cope with climate change, and; (4) developing conservation actions in response to climate change. Although signalled as a problem more than 2 decades ago (Mrosovsky et al. 1984, Davenport 1989), recent reviews by Hamann et al. (2007a), Hawkes et al. (2009) and Poloczanska et al. (2009) have highlighted the paucity of data available to accurately predict the impacts of climate change on sea turtles. To date, published studies have looked at impacts of climate change on nesting habitat, including sea level rise (Fish et al. 2005, Baker et al. 2006, Fuentes et al. 2010), extreme weather events (Pike \& Stiner 2007), geomorphology (Fuentes et al. in press), as well as anthropogenic development and the management of coastal areas (Rumbold et al. 2001, Kamel \& Mrosovsky 2006, Fish et al. 2008). Others have suggested that altered thermal regimes could change life history attributes, such as the timing of nesting seasons (Weishampel et al. 2004), hatchling sex ratios (Glen \& Mrosovsky 2004, Fuentes et al. 2009), and survival of incubating eggs (Hawkes et al. 2007). Some researchers have looked at how climate-driven changes to ocean systems may change the locations of developmental and foraging grounds as well as impacting their quality, either negatively or positively (McMahon \& Hays 2006, Chaloupka et al. 2008a, Saba et al. 2008, Witt et al. 2010). Applying recent methods of species distribution modelling using global data sets obtained through global data portals is also a promising new direction (Gilman et al. 2009). Although some researchers have emphasised promoting resilience in populations by alleviating other threats (Brander 2008, Robinson et al. 2009), less work has been done on understanding cumulative impacts or developing conservation responses to climate change, both of which are key areas for future research.

4.2. What are the major sources of fisheries bycatch and how can these be mitigated in ways that are ecologically, economically and socially practicable?

The questions on the bycatch of sea turtles focussed on (1) assessing captures and mortality of turtles per area and fishing gear, (2) understanding the impact on populations in terms of both turtle mortality and alteration of marine communities, and (3) developing technical changes to gear and working out policy strategies compatible with socio-economic needs to reduce bycatch impacts on turtle populations. Understanding the bycatch problem is difficult due to intrinsic uncertainties regarding catch levels, socio-economic factors, mortality rates and recovery rates that relate to sea turtle captures (Lewison et al. 2004a). First, the cumulative number of turtle captures cannot be accurately estimated because of (1) substantial variability in capture rates due to a myriad of possible combinations of technical and operational parameters within the same type of gear; (2) the number of unobserved vessels and limited availability of reliable fishing effort data; (3) the high levels of illegal, unregulated and unreported (IUU) fishing (Agnew et al. 2009); (4) the heterogeneous temporal, spatial, and life stage distribution of turtles; and (5) the need to consider species and populations independently (Lewison et al. 2004b, Casale 2008). Second, the mortality resulting from these captures is uncertain; mortality rates vary not only between different kinds of gear but also according to operational and technical parameters within each kind of gear (Sasso \& Epperly 2006, Casale et al. 2008). Third, the assessment of the impact of this mortality on populations requires substantial knowledge of population dynamics (Heppell et al. 1999; see Sections 3.1 and 3.2). Measures to mitigate mortality have been proposed mainly as technical changes and mainly to industrial fisheries (Epperly 2003, Gilman et al. 2006, 2010, Cox et al. 2007). Tackling the bycatch of sea turtles in the multitude of small-scale fisheries typical of coastal communities is intrinsically more difficult due to the great diversity of gear used in these fisheries and to the dispersed nature of the fishing communities (Soykan et al. 2008). However, some regional and local programmes dealing 
specifically with small-scale fishers have begun in recent years and have yielded some noticeable results (Gallo et al. 2006, Hall et al. 2007, Peckham et al. 2007, Abe \& Shiode 2009). It is uncertain to what extent specific technical measures can be effective in sea turtle conservation in the long term because they do not usually take into account other possible effects of fishing on the marine ecosystem (Pauly et al. 1998, Richardson et al. 2009). Sea turtle conservation in relation to fisheries should be based on close collaboration with fishers, and should be dealt with in a multidisciplinary way and in the context of population dynamics as well as from an ecosystem-based approach to fishery management (Costanza et al. 1998, Pikitch et al. 2004, Hall et al. 2007, Crowder et al. 2008).

A range of strategies are available that are potentially effective in lessening the impacts of fisheries on sea turtles: awareness and educational programmes, community-based conservation activities, marine protected areas, spatial/temporal closures of fisheries, national legislation and international agreements as well as gear-engineering solutions (Costanza et al. 1998, Hykle 1999, Marcovaldi et al. 2001, 2005, Campbell et al. 2002, Lewison et al. 2003, Food and Agriculture Organization of the United Nations 2005, 2009, Peckham et al. 2007, Witt et al. 2008). Many of these measures, when enacted unilaterally, are proving to be ineffective at promoting recovery of declining populations, because reducing bycatch mortality in one particular fishery or one geographic region does not address the myriad sources of mortality acting on different life stages, nor does it recognize the transboundary nature of sea turtles. A variety of policy instruments should be explored that address the sources of mortality at different life history stages. There is a need to examine the roles played by harvesters and consumers of seafood and the creation of economic incentives through market-based and other policy instruments, as opposed to command-and-control regulations, laws, and adverse incentives. Positive economic incentives help contribute toward a self-enforcing recovery strategy in a multilateral framework, emphasising cooperation and coordination among players (Dutton \& Squires 2008). Regardless of policy measures, more focus on the human dimensions associated with fishing and protected species bycatch is needed to improve outcomes of management practices (Marshall 2007, Campbell \& Cornwell 2008).

4.3. How can we evaluate the effects of anthropogenic factors on sea turtle habitats?

Human impacts on sea turtle habitats have been recognised for decades (Lutcavage et al. 1997), with efforts to mitigate impacts largely focused on terrestrial habitats (e.g. Witherington \& Martin 1996). There has been some progress in protecting and/or restoring marine ecosystems in certain areas (e.g. Molloy et al. 2009), but direct (e.g. disrupting ocean bottom with trawl and dredge fishing gear, Watling \& Norse 1998) and indirect (e.g. agricultural runoff, Diaz \& Rosenberg 2008; see Section 4.4) anthropogenic impacts to marine ecosystems continue to occur (Halpern et al. 2008). Sea turtle responses to altered terrestrial and marine ecosystems have been documented in some cases, including increased temperatures of hawksbill turtle nesting sites due to deforestation (Kamel \& Mrosovsky 2006) and alterations in overall diet of loggerhead turtles in response to changes in prey availability (Seney \& Musick 2007). More work is needed to evaluate the condition and status of sea turtle habitats and the threats to those habitats, and to determine how degradation of these habitats affects sea turtle populations. Important research areas related to restoration and mitigation of habitats include (1) developing frameworks to assess risks from cumulative impacts (likelihood and consequences scored across threats, life stages and reproductive value), (2) determining attributes of good quality habitat as well as mechanisms to protect this habitat and to evaluate the success of such measures, and (3) consideration of future threats and their management in decision processes (such as horizontal planning, Sutherland \& Woodroof 2009). The carrying capacity of a habitat is an important consideration in habitat restoration (Elliott et al. 2007). Some authors have sought to clarify historical or current carrying capacities of particular ecosystems (Jackson et al. 2001, Girondot et al. 2002), although much more work is needed in this area (see Section 3.4). Overall, improved dialogue across disciplines, and among researchers and end users, will no doubt improve the direction of research in understanding habitat alterations. Additionally, improvements in the availability of, and access to, remotely sensed data coupled with analysis tools such as GIS should provide novel insights about trends and can greatly assist in understanding the impacts of threats and effectiveness of mitigation (Grech \& Marsh 2008, Grech et al. 2008).

\subsection{What are the impacts of pollution on sea turtles and their habitats?}

The questions submitted relating to the impact of anthropogenic pollution on sea turtles suggested the need for accurate evaluation of the effects of pollutants on development, survivorship, health, reproduction, and habitat condition/recovery. Particularly highlighted was the need to evaluate the impact of plastics 
and other marine debris as well as the need to parameterise sublethal effects (e.g. dietary dilution or chemical absorption; McCauley \& Bjorndal 1999). Coastal and marine pollution is increasing dramatically throughout most of the world's coastal and oceanic zones (Laist et al. 1999, Derraik 2002, Moore 2008). In general, pollution in its many forms, such as sound, thermal, photic, plastics, chemical, effluent, and others, poses a threat to marine and terrestrial sea turtle habitats (see Section 4.3). Yet for most pollutants, little is known about critical thresholds and there are often few quantitative data linking them to mortality. Generally speaking, pollution of any type occurring above a certain threshold can render an area uninhabitable. At levels below that threshold, it can significantly degrade habitat quality, carrying capacity and other aspects of ecosystem function. To date, research has begun to elaborate potential effects on turtles (Hutchinson \& Simmonds 1991, 1992), in particular of solid debris (Carr 1987, Bugoni et al. 2001, Tomás et al. 2002, Mrosovsky et al. 2009), discarded fishing gear (Chatto et al. 1995, Leitch 2000, Monagas et al. 2008), heavy metals (Godley et al. 1999, Maffucci et al. 2005, Guirlet et al. 2008, García-Fernández et al. 2009), organochlorine pesticides (Keller et al. 2006, Ikonomopoulou et al. 2009), and oil pollution (Chan \& Liew 1988). Accumulation of debris at nesting beaches also has the potential to affect female nesting activity, embryo development and hatchling survival (Kasparek et al. 2001) and, in extremis, cause adult mortality (Laurance et al. 2008). Pollutants have been associated with the disease FP (Foley et al. 2005; see Section 4.5), immune system suppression (Keller et al. 2006), disruption of endocrine function (Ikonomopoulou et al. 2009), and possibly sex reversal in sea turtles (Bergeron et al. 1994, Stoker et al. 2003). Overall, the questions point towards the need for a better understanding of (1) pollution sources, and especially of non-point sources, (2) the factors influencing pollutant dispersal, (3) toxicology, (4) the vertical transfer from mother to offspring, (5) quantitative links between pollutant and impact, and (6) how to evaluate the use of incentives to minimise pollution

\subsection{What are the etiology and epidemiology of FP, and how can this disease be managed?}

Contributors were concerned with specifics such as (1) the environmental conditions associated with FP, (2) the cause of FP in sea turtles, (3) the mode of transmission, (4) the need to develop a more systematic assessment of global occurrence of FP in sea turtles, and (5) the need to develop robust diagnostic tests for detection of the herpesvirus (and potentially other viruses) associated with the disease. The presence of FP in sea turtles (mainly in green turtles) has been known since the 1930s (Smith \& Coates 1938); however, it was not until the last 15 years that concerted efforts have been made to understand the epidemiology and pathogenesis of this disease. FP is a major cause of stranding in turtles in Hawaii (Chaloupka et al. 2008c) and Florida (Foley et al. 2005) and has a global distribution (Herbst 1994). Unfortunately, compilations of systematic surveys of FP throughout the world do not exist. The pathology of FP has been well documented in the Western Atlantic (Jacobson et al. 1989, Norton et al. 1990) and Central Pacific (Aguirre et al. 1998, Work et al. 2004), but clear geographic differences exist in manifestation of this disease in green turtles (Aguirre et al. 2002), indicating that the pathology of the disease in other regions merits investigations. FP is transmissible experimentally (Herbst et al. 1995), and strong evidence exists of its association with a herpes virus (Lackovich et al. 1999, Quackenbush et al. 2001). Unfortunately, this virus continues to be refractory to laboratory cultivation (Work et al. 2009), thus impeding the development of ante-mortem tests to assess movement of the herpes virus through turtle populations. FP does not have a homogeneous geographic distribution, implicating environmental cofactors associated with disease; however, the role of these is unknown (Work et al. 2004). The mode of transmission is also unknown, although leeches have been implicated (Greenblatt et al. 2004). In terms of recovery and population level impacts, recent analysis of a 26 yr data set in Hawaii has demonstrated that although the disease is a main cause of strandings for the population, long-term tumour regression occurs, even in advanced cases (Chaloupka et al. 2009). Moreover, the Hawaiian green turtle population is recovering despite the prevalence of the disease in the 1980s and 1990s (Chaloupka et al. 2008c). Similar long-term data analyses on recovery rates are warranted for other areas with exposure.

\section{Conservation strategies}

Sea turtles are susceptible to human impacts at every life stage, from egg to hatchling, juvenile to adult, thereby placing them among the most conservationdependent of marine taxa. Designing appropriate sea turtle conservation measures relies on sound information on both the biology of sea turtles and the human social and economic dynamics that influence our ability to effect change in the status of sea turtle populations. Understanding the status of sea turtles is critical, as is knowledge of the human dimensions relating to sea turtle mortality. What constitutes effective conservation 
may vary with each species, and perhaps with each population. This has resulted in a variety of conservation frameworks and direct strategies for conservation that, although different across regions or localities, can be effective for promoting population recovery.

5.1. How can we effectively determine the conservation status of sea turtle populations?

The intentions, processes and outcomes of determining the status of sea turtles at species and/or population level has been debated in both the scientific and public domains since at least the mid 1980s. Central to the initial debates were the classification of hawksbill turtles (see Mrosovsky 1997a,b, 2000, Meylan \& Donnelly 1999), and similar arguments for other sea turtle species have followed (see reviews by Godfrey \& Godley 2008, Seminoff \& Shanker 2008). The dominant issue in these reviews is whether global assessments using the existing IUCN criteria are suitable for sea turtles. Questions in the section fell into 2 broad areas: (1) improvements to life history data availability and analysis for the determination of population/species trends, and (2) determining whether it is possible and useful to conduct status assessments. Clearly, status assessments for all species will benefit from increased data collection at a variety of scales (e.g. population trajectories in foraging as well as nesting aggregations), improved modelling techniques (see Sections 2.2 and 3.3), quantifiable data on threats and assignment of threats to populations (e.g. Sections 4.1 and 5.4) and increased understanding of the social, economic and legal aspects of assessments. To improve the usefulness of status assessments the main areas for future research should include (1) how to best define and classify the extinction risk of species - this would include improved use of population 'forecast' models, a broader threat-based approach and/or development of assessments based on other demographic trends aside from adult female abundance, (2) determining the relevant spatial scale that status assessments should encompass to best enhance conservation action (see Sections 2.1 and 3.3), and (3) determining whether status assessments at global or regional scales are useful conservation tools for designing and implementing national management policy, or in assisting governments and NGOs in their international responsibilities (see Section 2.1).

5.2. What are the most viable cultural, legal and socioeconomic frameworks for sea turtle conservation?

Research needs relating to the cultural, political, social, economic, and legal aspects of sea turtle con- servation are many and diverse. Questions were broadly categorised as addressing (1) individual behaviour, human values and psychology, and how a better understanding of these can assist conservation education and outreach, and ultimately change human behaviour, (2) broader social, political and economic structures, and actors (e.g. private sector interests, government and non-government organisations, communities) that influence conservation, (3) the costs and benefits of different conservation strategies, and how these are distributed among impacted human populations, and (4) legal and governance structures that can effectively manage migratory species, particularly in international waters. There was some tension within the category regarding the purpose of such research, between those with a utilitarian perspective, concerned with changing values, educating the public, or generating support for conservation, and those with a critical perspective, concerned with the political, cultural, and economic consequences of conservation. Overall, research on these topics has been limited, but is increasing. Much of this has been site specific or case based, and includes research on the role of sea turtles in subsistence culture (Bliege Bird \& Bird 1997, Bliege Bird et al. 2001); how conservation objectives impact on and are impacted by local communities (Campbell 1998, 1999, Bird et al. 2003, Campbell et al. 2007, Meletis \& Campbell 2009); comanagement of sea turtle fisheries and conservation (Granek \& Brown 2005, Campbell et al. 2009); the role of science and politics in sea turtle conservation (Campbell 2002, 2007, Jenkins 2002); conflicts associated with sea turtle conservation (Margavio \& Forsyth 1996, Santora 2003, Collomb 2009); the economic value of sea turtle based ecotourism (Wilson \& Tisdell 2001, Tisdell \& Wilson 2005a,b); and the phenomenon of volunteering for sea turtle conservation (Campbell \& Smith 2006, Gray \& Campbell 2007). Some of this work has been collated to address broader themes, for example, sea turtles as flagship species (Frazier 2005), international instruments (JIWLP 2002), cultural resources (Campbell 2002), direct payment schemes (Ferraro \& Gjertsen 2009), and consumptive use of olive ridley sea turtles (Campbell 2007; see Section 5.4). A variety of theoretical concepts from the social sciences (common property, decision analysis, international relations, political ecology, science and technology studies, etc.) are highly relevant to this field. Effectively integrating social science research with ecological or biological research remains a challenge (Campbell 2003), though emerging theoretical frameworks, e.g. social ecological systems theory, offer possibilities for guiding future inter-disciplinary work. 
5.3 Which conservation strategies are working (have worked) and which have failed?

Today's sea turtle conservation 'movement' can trace its roots to nesting beaches, where protection efforts started in the 1950s with a handful of projects and have since expanded to hundreds, if not thousands, of nesting beach conservation programmes worldwide (Frazier 2002). Protection of reproductive females at the nesting beach, especially when protection is maintained for 2 or more decades, has led to dramatic reversal in declines of previously over-exploited nesting populations (Mortimer \& Bresson 1994, Dutton et al. 2005, Broderick et al. 2006, Chaloupka et al. 2008b, Mortimer \& Donnelly 2008). Intervention efforts such as predator abatement and use of hatcheries continue to be widespread, and there is little doubt that these efforts have paid dividends for increasing hatchling production. In recent decades, the detriments of coastal artificial lighting to hatchlings have been mitigated in some areas with expanded use of lowsodium pressure lamps and light shields (Salmon et al. 2000). To meet the growing challenges of fisheries bycatch and marine habitat degradation (see Sections 4.2 and 4.3), there has been a gradual shift toward conservation in the marine realm. The development and proliferation of fishing 'gear fixes' and improved legislation that regulates where and when fishing occurs are 2 management strategies that have proven successful, albeit to varying degrees, depending on the country and fishery in question (Dryden et al. 2008). For example, turtle excluder devices (TEDs) on bottom trawl fisheries and circle hooks in longline fisheries have shown promise for reducing sea turtle bycatch mortality (Epperly 2003). In addition to these tools, bycatch reduction efforts have benefited from technological advances that have resulted in a better understanding of the spatio-temporal habitat requirements of sea turtles (Godley et al. 2008). This science-based approach ensures that fisheries operate in areas with low probability of turtle interactions and has enabled managers to set some areas off limits (e.g. time area closures) during times of peak turtle abundance (central California USA leatherback closure area). Marine protected areas (MPAs) have also been implemented, although with varying success for turtle conservation. While they may not be able to offer protection at ecological scales (i.e. to include all/most of the foraging, migration and nesting areas; Dryden et al. 2008), at smaller scales MPAs may be effective for protecting important foraging, internesting and/or nesting habitat (Dobbs et al. 2007, Dryden et al. 2008). In many cases, habitat protection and fisheries management benefit from national and international instruments and policies (e.g. US Endangered Species Act, IUCN, CITES, Convention on Migratory Species [CMS], Inter-American Convention for the Protection and Conservation of sea turtles [IAC]) that mandate reduction of turtle take or establish the legal framework to minimise the international trade of sea turtle products (Frazier 2002, Bache 2005). In some cases, these instruments have focused exclusively on turtles (e.g. IAC, Indian Ocean and Southeast Asian Memorandum of Understanding [IOSEA]), and provide clear mandates for cooperation among neighbouring countries. As new turtle conservation instruments have come online at the international scale, there has also been increased emphasis on implementation of community-based management and co-management arrangements operating at much smaller scales. Community-based conservation generally places greater recognition on the importance of the 'human element' in wildlife conservation and increased value on knowledge and values of local communities (Jentoft 2000, Pretty \& Smith 2004). These 2 approaches (international and local) are widely accepted as sound conservation actions by the wider sea turtle community. However, it is important to note that what constitutes 'effective conservation' has been, and will continue to be, open to debate, and there are inherent tensions between international vs. local approaches to sea turtle conservation (Campbell et al. 2002, Campbell 2007). For decades there have been wide-ranging opinions about the effectiveness of management strategies such as nesting beach hatcheries and headstarting (Frazer 1994), sustainable harvest (Mrosovsky 1997a,b, Campbell 2002; see Section 5.4), direct conservation payments (Ferraro \& Gjertsen 2009, see Section 5.2), and ecotourism (Tisdell \& Wilson 2005a,b, Campbell \& Smith 2006). Additionally, one of the challenges to determining success is that many management projects/ programmes are not designed and implemented with evaluation in mind (Sutherland et al. 2004). Designing management strategies with SMART (specific, measurable, achievable, realistic and timebased) goals that allow evaluation, adaptation and the development of evidence-based conservation will be key to determining management success of current and future projects. While no single conservation 'recipe' is appropriate for all occasions, the debates surrounding effectiveness have resulted in a greater recognition that the 'ethics' of conservation, and effective protection strategies are indeed not universal but may vary with each species, each management unit, and perhaps even each nesting rookery.

5.4. Under what conditions (ecological, environmental, social and political) can consumptive use of sea turtles be sustained?

The issue of consumptive use and whether it is, or could be, sustainable in sea turtle populations is widely debated and challenging to address (Campbell 2002). 
Essentially, this is because it intertwines ecological principles, species management, human rights, culture welfare, economic development and animal welfare (Nietschmann \& Nietschmann 1981, Campbell 1998, 2002, Kwan et al. 2006, Thiriet 2007, Tisdell et al. 2007, Daley et al. 2008). Historically, consumptive use has ranged from small-scale subsistence and/or cultural use of turtles or eggs through to large-scale systematic commercial take, such as for the turtle soup markets in the latter 19th century or the long-term commercial use of eggs. While there are empirical data linking some consumptive use, particularly commercial use, to population reductions (e.g. green and hawksbill turtles in Seychelles, Mortimer 1984; leatherback turtles in Malaysia, Chan \& Liew 1996), data on the level of take, status of the target species/population and socio-economic factors are lacking in most places. Importantly, recent research has indicated that depleted populations can recover, given appropriate management, and management does not necessarily exclude consumptive use (Havemann et al. 2005, Chaloupka \& Balazs 2007, Chaloupka et al. 2008b). Determining whether consumptive use is sustainable is challenging because the outcome is likely to vary at social, governance (local/state/country) and biological (species/population) scales and, especially for subsistence use, hunting patterns are strongly tied to the hybrid nature of the coastal economy and other commercial operations such as fishing and tourism (Kwan et al. 2006, Meletis \& Campbell 2007). Critical to the sustainability debate from a biological perspective is knowledge of the affected species and populations, and genetic studies such as population characterisation, and mixed stock analysis will be particularly informative here (e.g. Bass et al. 1998). Quantitative data on the size of the population, demography of animals taken and the level of use will be similarly important. Yet these data are absent for most populations and species. In addition, for most geographic areas where consumptive use occurs, data on social, cultural and economical factors related to sea turtles and their use are lacking. Focal areas worthy of research include (1) the sustainability of culture, local economy, health and social networks with and without consumptive use, (2) changes to the dynamics of local economies with and without consumptive use, (3) alternative options-dietary, cultural, economical, environmental offsets, (4) the importance of traditional ecological knowledge in sustaining consumptive use, both historically and currently, and (5) the multi-disciplinary challenges of conserving to consume, especially when there is a legal right to hunt, and the broader environmental consequences of reducing or replacing use. Another important research area, especially in assessing whether consumptive use remains sustainable, lies in under- standing and addressing cumulative risk and in understanding the links between legal and illegal use, which are made more problematic by the migratory nature of sea turtles.

\section{DISCUSSION}

Recent articles by Sutherland et al. (2006, 2009) highlight the value of expert opinion in identifying pertinent research questions that may facilitate and guide wildlife conservation. Harnessing the ideas of experts is powerful because it generates consensus about current topics as well as areas of research that may become more important in future years - such as improving our understanding of the threats to wildlife, how these threats are managed, and how applied management actions are evaluated. Moreover, the overlap across recommended research actions by individual experts underscores the need to enhance interdisciplinary research, and is an excellent way to highlight 'hotspot' research questions or topics. The synergy created by cross-sectional expert opinion can help focus attention on what is considered to be of immediate importance for conservation. These efforts also provide a baseline with which future assessments of the state of sea turtle conservation research and knowledge can be compared.

Sea turtles are generally regarded as species of conservation concern and in many places throughout world they are impacted by a variety of anthropogenic threats. With increased awareness of their ecological roles and struggles against burgeoning human pressures, coupled with growing enthusiasm for their protection, comes a need for increased knowledge of their biology and human-turtle-management interactions. However, the global distribution of sea turtles, the variety of habitats where they occur and the threats they face, all lead to a large diversity in the biophysical and human elements that influence their life history, ecological role and management.

Through a multinational, multidisciplinary team effort, we distilled what we believe are the most pertinent research themes related to sea turtle conservation into 20 metaquestions. Although there have been previous attempts to collate pertinent research questions related to sea turtle conservation (e.g. compilation of foraging area research priorities; Bjorndal 1999, Richardson 1999), these have either focused on particular issues (e.g. climate change; Hawkes et al. 2009) or have been overly general (e.g. 12 'Burning issues' for sea turtle research, compiled by the IUCN/Species Survival Commission MTSG, see Mast et al. 2006). What sets the current compilation apart is that we sought input from a diverse set of active researchers, 
allowing us to collate a wide variety of research foci and directions. In many cases, we also linked the research questions to conservation implications, a strategy we believe will encourage research efforts that feed directly into management actions, thus benefiting sea turtles and their habitats.

Despite the fact that sea turtles have been the focus of research and conservation efforts for several decades in various places around the world (Frazier 2003), many of the questions submitted by individual researchers highlighted the need to collect basic life history information. This reflects the ongoing information gaps related to the logistical challenges of studying sea turtles when they are dispersed in the open ocean (see Sections 2.2 and 3.3) and to the long time spans from hatchling to maturity. Our team also identified major knowledge gaps linking terrestrial habitats with the marine. For instance, there is a lack of longterm data on both hatchling sex ratios produced at various beaches worldwide and whether hatchling sex ratios persist into successive age classes over time (see Section 1.2). Overall, the general strategy is that improved collection of basic life history data would then contribute to modelling exercises that could be used to assess impacts and direct conservation efforts, although it is recognised that more effort is needed to develop models pertinent to sea turtle conservation.

There is a clear bias in the underlying questions and metaquestions towards the biological sciences. The bias in focus likely arises as a result of the number of participating authors with 'biology' as their primary interest. Nevertheless, in terms of sea turtle conservation over the next 10 years, there is a substantial need for the involvement of other disciplines and for interdisciplinary work. This need is evident not only in Section 5 which addresses strategies for conservation, but within each of the metaquestions in Section 4 there are key gaps identified that relate to human-threat-turtle links (see Section 4.2). More importantly, the need to understand the human dimensions of threats and impacts not only related to turtles but also to other processes such as ecosystem and economic function are key components of understanding impacts on sea turtles or their habitats and on the impact of management on socio-economic dimensions (Nicholson et al. 2009). Thus, the inclusion of other disciplines will be most important for understanding why threatening processes are occurring (e.g. bycatch and pollution) and assisting in the prioritisation, implementation and evaluation of multidisciplinary frameworks for species and habitat monitoring and management.

Although several participants in the exercise have research backgrounds but are now active in management roles, the approach taken in this exercise has essentially harnessed the expertise of one sector: research. Another exercise could be to expand the process laterally and include input from experts in environmental decision making and/or compare questions derived by experts for other groups of marine wildlife, or in the generalised field of marine conservation (Sutherland et al. 2009). Using data from managers and/or on other species, participants could rank and weight suggested questions to provide a more detailed analysis of questions pertinent to, or perhaps regionally relevant for, both single taxa and/or marine fauna management. Using this process and expanding the scope of the exercise, especially on a regional level, would be valuable as it is likely to provide useful synergies with other disciplines or groups of stakeholders and reduce the gap between science, policy and management. Indeed similar processes, such as horizontal scanning (Sutherland et al. 2008, Sutherland \& Woodroof 2009) or a prioritisation exercise used by (Nicholson et al. 2009) have demonstrated the effectiveness of using expert opinions, across a range of disciplines, to highlight a multi-disciplinary list of key current and emerging issues in conservation, plus the technological advances and/or challenges to guide management of the environment.

While the research questions highlighted here are considered to be of upmost priority at the current time, there is little doubt that priorities will change over time, due to both the progressive availability of information and also the dominant themes operating within conservation. For instance, the most frequently repeated question submitted by different authors was related to climate change impacts to sea turtles (28/347 total questions). In contrast, during a meeting of the IUCN MTSG in 2003, climate change was ranked last out of 12 'Burning issues' related to sea turtle research (Mast et al. 2004). Still, other priority research questions appear to remain more constant: bycatch evaluation and mitigation was the second most commonly submitted question in this exercise (27/347 questions) and was also the top 'Burning issue' in 2003 (Mast et al. 2004); bycatch mitigation was also recognised as the top priority for management in the Global Strategy for Sea Turtles (IUCN 1995). In addition, in 2006 the MTSG surveyed its membership to compile a list of the most important unanswered questions related to the natural history of sea turtles (Mast et al. 2006). Each of the 7 unresolved mysteries identified by the MTSG are covered to varying degrees in the 20 metaquestions; some such as ecological role, climate change impacts and FP are specifically contained in both sets.

Effective management of long-lived species such as sea turtles that occur in a broad range of habitats relies upon an appreciation of how biology and management fit within a variety of biophysical and social scales. While the priority question exercise has arrived at 20 
independent metaquestions, there are several links within and among them-system-based (individual scale through to populations, multi species and ecosystems), habitat-based (condition, status and threats), spatial scale (site specific through to ecological scale) and temporal scale (from single life stage through to life span). More importantly, it is clear from the descriptions for each question, especially those in Sections 4 and 5 that an appreciation of the links, and their dynamic nature across both space and time is pivotal in terms of prioritising research, monitoring and conservation actions for particular species, populations and/or systems. Therefore, the metaquestions and the descriptive text developed by this exercise should form a useful foundation for future research, management and management evaluation for sea turtle conservation.

Acknowledgements. The manuscript was improved by the input of the following people; Larisa Avens, Janice Blumenthal, Lucy Hawkes, Paul Richards, Wayne Fuller, Manjula Tiwari and 2 anonymous reviewers.

\section{LITERATURE CITED}

Abe O, Shiode D (2009) Development of sea turtle bycatch mitigation measures for pound net fisheries: a design concept to release turtles spontaneously. In: Gilman E (ed) Proc Technical Workshop on Mitigating Sea Turtle Bycatch in Coastal Net Fisheries, 20-22 January 2009, Honolulu, USA. Western Pacific Regional Fishery Management Council, IUCN, Southeast Asian Fisheries Development Center, Indian Ocean-South-East Asian Marine Turtle MoU, US National Marine Fisheries Service, Southeast Fisheries Science Center: Honolulu, HI; Gland; Bangkok; and Pascagoula, MS, p 43-44

Ackerman R (1997) The nest environment and the embryonic development of sea turtles. In: Lutz $\mathrm{P}$, Musick J (eds) The biology of sea turtles. CRC Press, Boca Raton, FL, p 83-106

Agnew DJ, Pearce J, Pramod G, Peatman T, Watson R, Beddington JR, Pitcher T (2009) Estimating the worldwide extent of illegal fishing. PLoS ONE 4:e4570

Aguilar R, Mas J, Pastor X (1995) Impact of Spanish swordfish longline fisheries on the loggerhead sea turtle Caretta caretta population in the western Mediterranean. In: Proc 12th Annu Workshop on Sea Turtle Biology and Conservation. NOAA Tech Memo NMFS-SEFSC-361:1-6

Aguirre AA, Spraker TR, Balazs GH, Zimmerman B (1998) Spirorchidiasis and fibropapillomatosis in green turtles from the Hawaiian Islands. J Wildl Dis 34:91-98

Aguirre AA, Balazs G, Spraker T, Murakawa S, Zimmerman B (2002) Pathology of oropharyngeal fibropapillomatosis in green turtles, Chelonia mydas. J Aquat Anim Health 14:298-304

Akçakaya HR (2000) Population viability analyses with demographically and spatially structured models. Ecol Bull 48:23-38

Alfaro Shigueto J, Mangel JC, Seminoff JA, Dutton PH (2008) Demography of loggerhead turtles Caretta caretta in the southeastern Pacific Ocean: fisheries-based observations and implications for management. Endang Species Res 5: $129-135$
Amorocho D (2002) Prioritising research driven management and public participation in sea turtle conservation in Columbia. MSc thesis, Australian National University, Canberra

Andrews AH, Tracey DM, Dunn MR (2009) Lead-radium dating of orange roughy (Hoplostethus atlanticus): validation of a centenarian life span. Can J Fish Aquat Sci 66: $1130-1140$

Aragones LV, Lawler IR, Foley WJ, Marsh H (2006) Dugong grazing and turtle cropping: grazing optimization in tropical seagrass systems. Oecologia 149:635-647

Avens L, Taylor JC, Goshe L, Jones T, Hastings M (2009) Use of skeletochronological analysis to estimate the age of leatherback sea turtles Dermochelys coriacea in the western North Atlantic. Endang Species Res 8:165-177

Avise JC (2007) Conservation genetics of marine turtles 10 years later. In: Fulbright TE, Hewitt DG (eds) Wildlife science: linking ecological theory and management applications. CRC Press, New York, NY, p 295-315

- Aznar FJ, Badillo FJ, Raga JA (1998) Gastrointestinal helminths of loggerhead turtles (Caretta caretta) from the Western Mediterranean: constraints on community structure. J Parasitol 84:474-479

Bache SJ (2005) Marine policy development: the impact of a flagship species. Marit Stud (MAST) 3/4:241-271

Baker JD, Littman CL, Johnston DW (2006) Potential effects of sea level rise on the terrestrial habitats of endangered and endemic megafauna in the Northwestern Hawaiian Islands. Endang Species Res 2:21-30

Balazs GH, Chaloupka M (2004) Spatial and temporal variability in somatic growth of green sea turtles resident within the Hawaiian Archipelago. Mar Biol 145: 1043-1059

Balazs GH, Pooley SG (1994) Research plan to assess marine turtle hooking mortality: results of an expert workshop held in Honolulu, Hawaii, November 16-18, 1993. NOAA Tech Memo NMFS-SWFSC 201:1-41 Honolulu, HI

> Bass AL, Lagueux CJ, Bowen BW (1998) Origin of green turtles, Chelonia mydas, at 'sleeping rocks' off the northeast coast of Nicaragua. Copeia 1998:1064-1069

> Bell BA, Spotila JR, Paladino FV, Reina RD (2004) Low reproductive success of leatherback turtles, Dermochelys coriacea, is due to high embryonic mortality. Biol Conserv 115:131-138

Bell CDL, Solomon JL, Blumenthal JM, Austin TJ, EbanksPetrie G, Broderick AC, Godley BJ (2007) Monitoring and conservation of critically reduced marine turtle nesting populations: lessons from the Cayman Islands. Anim Conserv 10:39-47

Bell CD, Blumenthal JM, Broderick AC, Godley BJ (2009) Investigating potential for depensation in marine turtles: How low can you go? Conserv Biol 24:226-235

Bellagio Steering Committee (2004) What can be done to restore Pacific turtle populations? The Bellagio Blueprint for Action on Pacific Sea Turtles, World Fish Center, Penang

Benson SR, Dutton PH, Hitipeuw C, Samber B, Bakarbessy J, Parker D (2007a) Post-nesting migrations of leatherback turtles (Dermochelys coriacea) from Jamursba-Medi, Bird's Head Peninsula, Indonesia. Chelonian Conserv Biol 6:150-154

Benson SR, Kisokau KM, Ambio L, Rei V, Dutton PH, Parker D (2007b) Beach use, internesting movement, and migration of leatherback turtles, Dermochelys coriacea, nesting on the north coast of Papua New Guinea. Chelonian Conserv Biol 6:7-14

> Bergeron JM, Crews D, McLachlan JA (1994) PCBs as environmental estrogens-turtle sex determination as a bio- 
marker of environmental contamination. Environ Health Perspect 102:780-781

Bertolotti L, Salmon M (2005) Do embedded roadway lights protect sea turtles? Environ Manag 36:702-710

Bird K, Nichols W, Tambiah C (2003) The value of local knowledge in sea turtle conservation: a case from Baja California, Mexico. University of British Columbia Fisheries Centre Research Reports 11:178-183

Bjorndal KA (1997) Foraging ecology and nutrition of sea turtles. In: Lutz P, Musick J (eds) The biology of sea turtles. CRC Press, Boca Raton FL, p 199-231

Bjorndal KA (1999) Priorities for research in foraging habitats. In: Eckert K, Bjorndal KA, Abreu-Gorbois A, Donnelly M (eds) Research and management techniques for the conservation of sea turtles. IUCN-SSC Marine Turtle Specialist Group, No. 4, p 12-15

Bjorndal KA (2003) Roles of loggerhead sea turtles in marine ecosystems. In: Bolten A, Witherington B (eds) Loggerhead sea turtles. Smithsonian Institution Press, Washington, DC, p 235-254

Bjorndal KA, Jackson JBC (2003) Roles of sea turtles in marine ecosystems: reconstructing the past. In: Lutz $\mathrm{P}$, Musick J, Wyneken J (eds) The biology of sea turtles, Vol II. CRC Press, Boca Raton, FL, p 259-273

Bjorndal KA, Bolten AB, Lagueux CJ, Chaves A (1996) Probability of tag loss in green turtles nesting at Tortuguero, Costa Rica. J Herpetol 30:567-571

Bjorndal KA, Bolten AB, Martins HR (2000) Somatic growth model of juvenile loggerhead sea turtles Caretta caretta: duration of pelagic stage. Mar Ecol Prog Ser 202: 265-272

Bjorndal KA, Bolten AB, Koike B, Schroeder BA, Shaver DJ, Teas WG, Witzell WN (2001) Somatic growth function for immature loggerhead sea turtles, Caretta caretta, in southeastern US waters. Fish Bull 99:240-246

Bjorndal KA, Bolten AB, Dellinger T, Delgado C, Martins HR (2003a) Compensatory growth in oceanic loggerhead sea turtles: response to a stochastic environment. Ecology 84:1237-1249

Bjorndal KA, Bolten AB, Martins HR (2003b) Estimates of survival probabilities for oceanic-stage loggerhead sea turtles (Caretta caretta) in the North Atlantic. Fish Bull 101:732-736

Blanvillain G, Pease AP, Segars AL, Rostal DC, Richards AJ, Owens DW (2008) Comparing methods for the assessment of reproductive activity in adult male loggerhead sea turtles Caretta caretta at Cape Canaveral, Florida. Endang Species Res 6:75-85

Bliege Bird RL, Bird DW (1997) Delayed reciprocity and tolerated theft: the behavioral ecology of food-sharing strategies. Curr Anthropol 38:49-78

Bliege Bird R, Smith EA, Bird DW (2001) The hunting handicap: costly signaling in human foraging strategies. Behav Ecol Sociobiol 50:9-19

Blumenthal JM, Solomon JL, Bell CD, Austin TJ and others (2006) Satellite tracking highlights the need for international cooperation in marine turtle management. Endang Species Res 2:51-61

Blumenthal JM, Abreu-Grobois FA, Austin TJ, Broderick AC and others (2009) Turtle groups or turtle soup: dispersal pattern of hawksbill turtles in the Caribbean. Mol Ecol 18: 4841-4853

Bolker BM, Okuyama T, Bjorndal KA, Bolten AB (2007) Incorporating multiple mixed stocks in mixed stock analysis: 'many-to-many' analyses. Mol Ecol 16:685-695

Bolten AB (2003) Active swimmers-passive drifters: the oceanic juvenile stage of loggerheads in the Atlantic system.
In: Bolten A, Witherington B (eds) Loggerhead sea turtles. Smithsonian Institution Press, Washington, DC, p 63-78

Bolten AB, Martins HR, Bjorndal KA, Gordon J (1993) Size distribution of pelagic-stage loggerhead sea turtles (Caretta caretta) in the waters around the Azores and Madeira. Arquipel Life Mar Sci 11A:49-54

> Bolten AB, Bjorndal KA, Martins HR, Dellinger T, Biscoito MJ, Encalada SE, Bowen BW (1998) Transatlantic developmental migrations of loggerhead sea turtles demonstrated by mtDNA sequence analysis. Ecol Appl 8:1-7

Booth DT (2009) Swimming for your life: locomotor effort and oxygen consumption during the green turtle (Chelonia mydas) hatchling frenzy. J Exp Biol 212:50-55

> Bouchard SS, Bjorndal KA (2000) Sea turtles as biological transporters of nutrients and energy from marine to terrestrial ecosystems. Ecology 81:2305-2313

Bowen BW (1995) Tracking marine turtles with genetic-markers-voyages of the ancient mariners. Bioscience 45: $528-534$

> Bowen BW, Karl SA (2007) Population genetics and phylogeography of sea turtles. Mol Ecol 16:4886-4907

Bowen BW, Abreu-Grobois FA, Balazs GH, Kamezaki N, Limpus CJ, Ferl RJ (1995) Trans-Pacific migrations of the loggerhead turtle (Caretta Caretta) demonstrated with mitochondrial-DNA markers. Proc Natl Acad Sci USA 92:3731-3734

> Boyle MC, FitzSimmons NN, Limpus CJ, Kelez S, VelezZuazo X, Waycott M (2009) Evidence for transoceanic migrations by loggerhead sea turtles in the southern Pacific Ocean. Proc Biol Sci 276:1993-1999

- Brander K (2008) Tackling the old familiar problems of pollution, habitat alteration and overfishing will help with adapting to climate change. Mar Pollut Bull 56:1957-1958

Braun-McNeill J, Epperly S, Avens L, Snover M, Taylor J (2008) Growth rates of loggerhead sea turtles (Caretta caretta) from the western North Atlantic. Herpetol Conserv Biol 3:273-281

Briane JP, Rivalan P, Girondot M (2007) The inverse problem applied to the observed clutch frequency of leatherback turtles from Yalimapo Beach, French Guiana. Chelonian Conserv Biol 6:63-69

Broderick AC, Godley BJ, Reece S, Downie JR (2000) Incubation periods and sex ratios of green turtles: highly female biased hatchling production in the eastern Mediterranean. Mar Ecol Prog Ser 202:273-281

> Broderick AC, Glen F, Godley BJ, Hays GC (2003) Variation in reproductive output of marine turtles. J Exp Mar Biol Ecol 288:95-109

Broderick AC, Frauenstein R, Glen F, Hays GC and others (2006) Are green turtles globally endangered? Glob Ecol Biogeogr 15:21-26

> Bugoni L, Krause L, Petry MV (2001) Marine debris and human impacts on sea turtles in southern Brazil. Mar Pollut Bull 42:1330-1334

Campbell LM (1998) Use them or lose them? Conservation and the consumptive use of marine turtle eggs at Ostional, Costa Rica. Environ Conserv 25:305-319

Campbell LM (1999) Ecotourism in rural developing communities. Ann Tourism Res 26:534-553

Campbell LM (2002) Science and sustainable use: views of marine turtle conservation efforts. Ecol Appl 12:1229-1246

Campbell LM (2003) Challenges for interdisciplinary sea turtle research: perspectives of a social scientist. Mar Turtle Newsl 100:28-32

> Campbell LM (2007) Local conservation practice and global discourse: a political ecology of sea turtle conservation. Ann Assoc Am Geogr 97:313-334 
Campbell LM, Cornwell ML (2008) Human dimensions of bycatch reduction technology: current assumptions and directions for future research. Endang Species Res 5: 325-334

Campbell LM, Smith C (2006) What makes them pay? Values of volunteer tourists working for sea turtle conservation. Environ Manag 38:84-98

Campbell LM, Godfrey MH, Drif O (2002) Community-based conservation via global legislation? Limitations of the Inter-American Convention for the Protection and Conservation of Sea Turtles. J Int Wildl Law Policy 5:121-143

- Campbell LM, Haalboom BJ, Trow J (2007) Sustainability of community-based conservation: sea turtle egg harvesting in Ostional (Costa Rica) ten years later. Environ Conserv 34:122-131

Campbell LM, Silver JJ, Gray NJ, Ranger S and others (2009) Co-management of sea turtle fisheries: biogeography versus geopolitics. Mar Pol 33:137-145

Carr AF (1986) Rips, FADS, and little loggerheads. Bioscience 36:92-100

$>$ Carr AF (1987) Impact of nondegradable marine debris on the ecology and survival outlook of sea turtles. Mar Pollut Bull 18:352-356

Carreras C, Pont S, Maffucci F, Pascual M and others (2006) Genetic structuring of immature loggerhead sea turtles (Caretta caretta) in the Mediterranean Sea reflects water circulation patterns. Mar Biol 149:1269-1279

Casal AB, Oros J (2007) Morphologic and cytochemical characteristics of blood cells of juvenile loggerhead sea turtles (Caretta caretta). Res Vet Sci 82:158-165

Casale P (2008) Incidental catch of marine turtles in the Mediterranean Sea: captures, mortality, priorities. WWF Italy, Rome

> Casale P, Freggi D, Rocco M (2008) Mortality induced by drifting longline hooks and branchlines in loggerhead sea turtles, estimated through observation in captivity. Aquat Conserv: Mar Freshw Ecosyst 18:945-954

Caut S, Hulin V, Girondot M (2006) Impact of density-dependent nest destruction on emergence success of Guianan leatherback turtles. Anim Conserv 9:189-197

> Caut S, Fossette S, Guirlet E, Angulo E, Das K, Girondot M, Georges JY (2008) Isotope analysis reveals foraging area dichotomy for Atlantic leatherback turtlese1845. PLoS ONE 3:e1845

> Chaloupka M (2001) Historical trends, seasonality and spatial synchrony in green turtle egg production. Biol Conserv 101:263-279

> Chaloupka M (2002) Stochastic simulation modelling of southern Great Barrier Reef green turtle population dynamics. Ecol Model 148:79-109

Chaloupka M (2004) Exploring the metapopulation dynamics of the southern Great Barrier Reef green turtle stock and possible consequences of sex-biased local harvesting. In: Akçakaya H, Burgman M, Kindvall O, Wood C, SjogrenGulve P, Hattfield J, McCarthy M (eds) Species conservation and management: case studies. Oxford University Press, New York, NY, p 340-354

Chaloupka M, Balazs G (2005) Modelling the effect of fibropapilloma disease on the somatic growth dynamics of Hawaiian green sea turtles. Mar Biol 147:1251-1260

Chaloupka M, Balazs G (2007) Using Bayesian state-space modelling to assess the recovery and harvest potential of the Hawaiian green sea turtle stock. Ecol Model 205: 93-109

Chaloupka MY, Limpus CJ (1997) Robust statistical modelling of hawksbill sea turtle growth rates (southern Great Barrier Reef). Mar Ecol Prog Ser 146:1-8
Chaloupka M, Limpus C (2001) Trends in the abundance of sea turtles resident in southern Great Barrier Reef waters. Biol Conserv 102:235-249

> Chaloupka M, Limpus C (2005) Estimates of sex- and ageclass-specific survival probabilities for a southern Great Barrier Reef green sea turtle population. Mar Biol 146:1251-1261

Chaloupka M, Limpus C, Miller J (2004a) Green turtle somatic growth dynamics in a spatially disjunct Great Barrier Reef metapopulation. Coral Reefs 23:325-335

> Chaloupka M, Parker D, Balazs G (2004b) Modelling postrelease mortality of loggerhead sea turtles exposed to the Hawaii-based pelagic longline fishery. Mar Ecol Prog Ser 280:285-293

> Chaloupka M, Kamezaki N, Limpus C (2008a) Is climate change affecting the population dynamics of the endangered Pacific loggerhead sea turtle? J Exp Mar Biol Ecol 356:136-143

Chaloupka M, Bjorndal KA, Balazs GH, Bolten AB and others (2008b) Encouraging outlook for recovery of a once severely exploited marine megaherbivore. Glob Ecol Biogeogr 17:297-304

> Chaloupka M, Work TM, Balazs GH, Murakawa SKK, Morris $\mathrm{R}$ (2008c) Cause-specific temporal and spatial trends in green sea turtle strandings in the Hawaiian Archipelago (1982-2003). Mar Biol 154:887-898

> Chaloupka M, Balazs GH, Work T (2009) Rise and fall over 26 years of a marine epizootic in Hawaiian green sea turtles. J Wildl Dis 45:1138-1142

Chan EH, Liew HC (1988) A review of the effects of oil-based activities and oil pollution on sea turtles. In: Sasekumar A, D'Cruz R, Lim SLH (eds) Thirty years of marine science research and development. Proc 11th Annu Seminar of the Malaysian Society of Marine Science, Kuala Lumpur, p 159-168

Chan E, Liew H (1996) Decline of the leatherback population in Terengganu, Malaysia, 1956-1995. Chelonian Conserv Biol 2:196-203

Chatto R, Guinea M, Conway S (1995) Sea turtles killed by flotsam in northern Australia. Mar Turtle Newsl 69:17-18

Collomb G (2009) Sous les tortues, la plage? Protection de la nature et production des territoires en Guyane. Ethonologie française XXXIX:11-21

Conant TA, Dutton PH, Eguchi T, Epperly SP and others (2009) Loggerhead sea turtle (Caretta caretta) 2009 status review under the U.S Endangered Species Act. Report of the loggerhead biological review Team to the National Marine Fisheries Service, August 2009, Silver Spring, MD

Costanza R, dArge $\mathrm{R}$, deGroot $\mathrm{R}$, Farber $\mathrm{S}$ and others $\mathrm{M}$ (1997) The value of the world's ecosystem services and natural capital. Nature 387:253-260

Costanza R, Andrade F, Antunes P, van den Belt M and others (1998) Principles for sustainable governance of the oceans. Science 281:198-199

Cox TM, Lewison RL, Zydelis R, Crowder LB, Safina C, Read AJ (2007) Comparing effectiveness of experimental and implemented bycatch reduction measures: the ideal and the real. Conserv Biol 21:1155-1164

CPPS (Comisión Permanente del Pacífico Sur) (2006) Plan de Accíon para la Protección del Medio Marino Áreas Costeras del Pacífico Sudeste. Comisión Permanente del Pacífico Sur, Guayaquil

> Crouse DT, Crowder LB, Caswell H (1987) A stage-based population model for loggerhead sea turtles and implications for conservation. Ecology 68:1412-1423

Crowder LB, Hazen EL, Avissar N, Bjorkland R, Latanich C, Ogburn MB (2008) The impacts of fisheries on marine 
ecosystems and the transition to ecosystem-based management. Annu Rev Ecol Evol Syst 39:259-278

Daley B, Griggs P, Marsh H (2008) Exploiting marine wildlife in Queensland: the commercial dugong and marine turtle fisheries, 1847-1969. Aust Econ Hist Rev 48:227-265

Davenport J (1989) Sea turtles and the greenhouse effect. Br Herpetol Soc Bull 29:11-15

> Deem SL, Dierenfield ES, Sounguet GP, Alleman AR and others (2006) Hematologic values in free-ranging leatherback turtles (Dermochelys coriacea) nesting on Pongara Beach, Republic of Gabon. J Zoo Wildl Med 37:464-471

> Derraik JGB (2002) The pollution of the marine environment by plastic debris: a review. Mar Pollut Bull 44:842-852

- Dethmers KEM, Broderick D, Moritz C, FitzSimmons NN and others (2006) The genetic structure of Australasian green turtles (Chelonia mydas): exploring the geographical scale of genetic exchange. Mol Ecol 15:3931-3946

> Diaz RJ, Rosenberg R (2008) Spreading dead zones and consequences for marine ecosystems. Science 321:926-929

Dobbs KA, Miller JD, Limpus CJ, Landry AM Jr (1999) Hawksbill turtle, Eretmochelys imbricata, nesting at Milman Island, northern Great Barrier Reef, Australia. Chelonian Conserv Biol 3:344-361

Dobbs KA, Fernandes L, Slegers S, Jago B and others (2007) Incorporating marine turtle habitats into the marine protected area design for the Great Barrier Reef Marine Park, Queensland, Australia. Pac Conserv Biol 13:293-303

> Dryden J, Grech A, Moloney J, Hamann M (2008) Rezoning of the Great Barrier Reef World Heritage Area: Does it afford greater protection for marine turtles? Wildl Res 35: 477-485

Dutton PH, Squires D (2008) Reconciling biodiversity with fishing: a holistic strategy for Pacific sea turtle recovery. Ocean Dev Int Law 39:200-222

Dutton PH, Bowen BW, Owens DW, Barragan A, Davis SK (1999) Global phylogeography of the leatherback turtle (Dermochelys coriacea). J Zool 248:397-409

> Dutton DL, Dutton PH, Chaloupka M, Boulon RH (2005) Increase of a Caribbean leatherback turtle Dermochelys coriacea nesting population linked to long-term nest protection. Biol Conserv 126:186-194

> Dutton PH, Balazs GH, LeRoux RA, Murakawa SKK, Zarate P, Martínez LS (2008) Composition of Hawaiian green turtle foraging aggregations: mtDNA evidence for a distinct regional population. Endang Species Res 5:37-44

Elliott M, Burdon D, Hemingway KL, Apitz SE (2007) Estuarine, coastal and marine ecosystem restoration: confusing management and science - a revision of concepts. Estuar Coast Shelf Sci 74:349-366

Engeman RM, Martin RE, Smith HT, Woolard J and others (2005) Dramatic reduction in predation on marine turtle nests through improved predator monitoring and management. Oryx 39:318-326

Epperly SP (2003) Fisheries-related mortality and Turtle Excluder Devices (TEDs). In: Lutz P, Musick J, Wyneken J (eds) The biology of sea turtles, Vol II. CRC Press, Boca Raton, FL, p 339-353

Epperly SP, Braun J, Chester AJ, Cross FA, Merriner JV, Tester PA, Churchill JH (1996) Beach strandings as an indicator of at-sea mortality of sea turtles. Bull Mar Sci 59:289-297

Ferraro PJ, Gjertsen H (2009) A global review of incentive payments for sea turtle conservation. Chelonian Conserv Biol 8:48-56

> Fish MR, Cote IM, Gill JA, Jones AP, Renshoff S, Watkinson AR (2005) Predicting the impact of sea-level rise on Caribbean sea turtle nesting habitat. Conserv Biol 19: 482-491
Fish MR, Cote IM, Horrocks JA, Mulligan B, Watkinson AR, Jones AP (2008) Construction setback regulations and sea-level rise: mitigating sea turtle nesting beach loss. Ocean Coast Manag 51:330-341

> FitzSimmons NN, Limpus CJ, Norman JA, Goldizen AR, Miller JD, Moritz C (1997) Philopatry of male marine turtles inferred from mitochondrial DNA markers. Proc Natl Acad Sci USA 94:8912-8917

Foley AM, Schroeder BA, Redlow AE, Fick-Child KJ, Teas WG (2005) Fibropapillomatosis in stranded green turtles (Chelonia mydas) from the eastern United States (198098): trends and associations with environmental factors. J Wildl Dis 41:29-41

Food and Agriculture Organization of the United Nations (2005) Report of the technical consultation on sea turtles conservation and fisheries. Report No. 756. FAO, Rome

Food and Agriculture Organization of the United Nations (2009) Guidelines to reduce sea turtle mortality in fishing operations. FAO, Rome

Frazer NB (1994) Sea turtle headstarting and hatchery programs. In: Meffe GK, Carroll CR (eds) Principles of conservation biology. Sinauer Associates, Sunderland, MA, p $374-380$

Frazier J (2002) Marine turtles and international instruments: The agony and the ecstasy. J Int Wildl Law Policy 5:1-10

Frazier J (2003) Prehistoric and ancient historic interactions between humans and marine turtles. In: Lutz P, Musick J, Wyneken J (eds) The biology of sea turtles, Vol II. CRC Press, Boca Raton, FL, p 1-38

Frazier J (2005) The role of flagship species in interactions between people and the sea. Marit Stud (MAST) 3:5-39

> Fuentes MMPB, Maynard JA, Guinea M, Bell IP, Werdell PJ, Hamann M (2009) Proxy indicators of sand temperature help project impacts of global warming on sea turtles in northern Australia. Endang Species Res 9:33-40

> Fuentes MMPB, Limpus CJ, Hamann M, Dawson J (2010) Community assistance to determine the potential affects of projected sea level rise to marine turtles. Aquat Conserv: Mar Freshw Ecosyst 20:132-139

Fuentes M, Dawson J, Smithers S, Limpus C, Hamann M (2010) Variable sedimentology at key sea turtle rookeries: implications for sea turtles under projected climate change. Mar Freshw Res 61:464-473

Gallo BMG, Macedo S, Giffoni BD, Becker JH, Barata PCR (2006) Sea turtle conservation in Ubatuba, southeastern Brazil, a feeding area with incidental capture in coastal fisheries. Chelonian Conserv Biol 5:93-101

> García-Fernández AJ, Gomez-Ramirez P, Martinez-Lopez E, Hernandez-Garcia A and others (2009) Heavy metals in tissues from loggerhead turtles (Caretta caretta) from the southwestern Mediterranean (Spain). Ecotoxicol Environ Saf 72:557-563

Gilman E, Zollett E, Beverly S, Nakano H and others (2006) Reducing sea turtle by-catch in pelagic longline fisheries. Fish Fish 7:2-23

Gilman E, Gearhart J, Price B, Eckert S and others (2010) Mitigating sea turtle by-catch in coastal passive net fisheries. Fish Fish 11:57-88

Gilman E, King N, Peterson T, Chavan V, Hahn A (2009) Building the biodiversity data commons - the global biodiversity information facility. In: Maurer L (ed) ICT for agriculture and biodiversity conservation. ICT Ensure, Graz University of Technology, Graz, p 79-99

Girondot M, Fouillet H, Pieau C (1998) Feminizing turtle embryos as a conservation tool. Conserv Biol 12:353-362

Girondot M, Tucker AD, Rivalan P, Godfrey MH, Chevalier J (2002) Density-dependent nest destruction and population 
fluctuations of Guianan leatherback turtles. Anim Conserv 5:75-84

Glen F, Mrosovsky N (2004) Antigua revisited: the impact of climate change on sand and nest temperatures at a hawksbill turtle (Eretmochelys imbricata) nesting beach. Glob Change Biol 10:2036-2045

> Godfrey M, Godley B (2008) Seeing past the red: flawed IUCN global listings for sea turtles. Endang Species Res 6:155-159

Godley BJ, Thompson DR, Furness RW (1999) Do heavy metal concentrations pose a threat to marine turtles from the Mediterranean Sea? Mar Pollut Bull 38:497-502

Godley BJ, Broderick AC, Downie JR, Glen F and others (2001) Thermal conditions in nests of loggerhead turtles: further evidence suggesting female skewed sex ratios of hatchling production in the Mediterranean. J Exp Mar Biol Ecol 263:45-63

Godley BJ, Blumenthal JM, Broderick AC, Coyne MS, Godfrey MH, Hawkes LA, Witt MJ (2008) Satellite tracking of sea turtles: Where have we been and where do we go next? Endang Species Res 4:3-22

Godley BJ, Barbosa C, Bruford M, Broderick AC and others (in press) Unravelling migratory connectivity in marine turtles using multiple methods. J Appl Ecol

> Gordon AN, Kelly WR, Cribb TH (1998) Lesions caused by cardiovascular flukes (Digenea: Spirorchidae) in stranded green turtles (Chelonia mydas). Vet Pathol 35:21-30

Granek EF, Brown MA (2005) Co-management approach to marine conservation in Moheli, Comoros Islands. Conserv Biol 19:1724-1732

Gray NJ, Campbell LM (2007) A decommodified experience? Exploring aesthetic, economic and ethical values for volunteer ecotourism in Costa Rica. J Sustainable Tourism 15:463-482

Grech A, Marsh H (2008) Rapid assessment of risks to a mobile marine mammal in an ecosystem-scale marine protected area. Conserv Biol 22:711-720

Grech A, Marsh H, Coles R (2008) A spatial assessment of the risk to a mobile marine mammal from bycatch. Aquat Conserv: Mar Freshw Ecosyst 18:1127-1139

> Greenblatt RJ, Work TM, Balazs GH, Sutton CA, Casey RN, Casey JW (2004) The Ozobranchus leech is a candidate mechanical vector for the fibropapilloma-associated turtle herpesvirus found latently infecting skin tumors on Hawaiian green turtles (Chelonia mydas). Virology 321: 101-110

Greiner EC, Forrester DJ, Jacobson ER (1980) Helminths of mariculture-reared green turtles (Chelonia mydas) from Grand Canyon, British West Indies. Proc Helminthol Soc Wash 47:142-144

Gross TS, Crain DA, Bjorndal KA, Bolten AB, Carthy RR (1995) Identification of sex in hatchling loggerhead sea turtles (Caretta caretta) by analysis of steroid concentrations in chorioallantoic/amniotic fluid. Gen Comp Endocrinol 99:204-210

Guirlet E, Das K, Girondot M (2008) Maternal transfer of trace elements in leatherback turtles (Dermochelys coriacea) of French Guiana. Aquat Toxicol 88:267-276

Hall M, Nakano H, Clarke S, Thomas S and others (2007) Working with fishers to reduce by-catches. In: Kennelly SJ (ed) By-catch reduction in the world's fisheries. Springer, Dordrecht, p 235-288

Halpern BS, Walbridge S, Selkoe KA, Kappel CV and others (2008) A global map of human impact on marine ecosystems. Science 319:948-952

Hamann M, Limpus C, Read M (2007a) Vulnerability of marine reptiles to climate change in the Great Barrier
Reef. In: Johnson J, Marshal P (eds) Climate change and the Great Barrier Reef. Great Barrier Reef Marine Park Authority and The Australian Greenhouse Office, Canberra, p 235-288

> Hamann M, Jessop TS, Schauble CS (2007b) Fuel use and corticosterone dynamics in hatchling green sea turtles (Chelonia mydas) during natal dispersal. J Exp Mar Biol Ecol 353:13-21

> Hatase H, Matsuzawa Y, Sakamoto W, Baba N, Miyawaki I (2002a) Pelagic habitat use of an adult Japanese male loggerhead turtle Caretta caretta examined by the Argos satellite system. Fish Sci 68:945-947

Hatase H, Takai N, Matsuzawa Y, Sakamoto W and others (2002b) Size-related differences in feeding habitat use of adult female loggerhead turtles Caretta caretta around Japan determined by stable isotope analyses and satellite telemetry. Mar Ecol Prog Ser 233:273-281

Havemann PTD, Marsh H, Jones C (2005) Traditional use of marine resources agreements and dugong hunting in the Great Barrier Reef World Heritage Area. Environ Planning Law J 22:258-280

Hawkes LA, Broderick AC, Coyne MS, Godfrey MH and others (2006) Phenotypically linked dichotomy in sea turtle foraging requires multiple conservation approaches. Curr Biol 16:990-995

Hawkes LA, Broderick AC, Godfrey MH, Godley BJ (2007) Investigating the potential impacts of climate change on a marine turtle population. Global Change Biol 13:923-932

Hawkes LA, Broderick AC, Godfrey MH, Godley BJ (2009) Climate change and marine turtles. Endang Species Res $7: 137-154$

- Hays GC (2000) The implications of variable remigration intervals for the assessment of population size in marine turtles. J Theor Biol 206:221-227

Hays GC, Mackay A, Adams CR, Mortimer JA, Speakman JR, Boerema M (1995) Nest site selection by sea turtles. J Mar Biol Assoc UK 75:667-674

Hays GC, Akesson S, Broderick AC, Glen F and others (2001) The diving behaviour of green turtles undertaking oceanic migration to and from Ascension Island: dive durations, dive profiles and depth distribution. J Exp Biol 204:4093-4098

> Hays GC, Houghton JDR, Isaacs C, King RS, Lloyd C, Lovell P (2004) First records of oceanic dive profiles for leatherback turtles, Dermochelys coriacea, indicate behavioural plasticity associated with long-distance migration. Anim Behav 67:733-743

- Heithaus M, McLash J, Frid A, Dill L, Marshall G (2002) Novel insights into green sea turtle behaviour using animalborne video cameras. J Mar Biol Assoc UK 82:1049-1050

Heithaus MR, Frid A, Wirsing AJ, Dill LM and others (2007) State-dependent risk-taking by green sea turtles mediates top-down effects of tiger shark intimidation in a marine ecosystem. J Anim Ecol 76:837-844

- Heithaus MR, Wirsing AJ, Thomson JA, Burkholder DA (2008) A review of lethal and non-lethal effects of predators on adult marine turtles. J Exp Mar Biol Ecol 356: 43-51

Hendrickson J (1958) The green sea turtle, Chelonia mydas (Linn.) in Malaya and Sarawak. Proc Zool Soc Lond 130:455-535

- Heppell SS (1998) Application of life history theory and population model analysis to turtle conservation. Copeia 367-375

Heppell S, Crowder L, Menzel T (1999) Life table analysis of long-lived marine species with implications for conservation and management. Am Fish Soc Symp 23:137-148 
Heppell SS, Caswell H, Crowder LB (2000) Life histories and elasticity patterns: perturbation analysis for species with minimal demographic data. Ecology 81:654-665

Heppell SS, Crouse DT, Crowder LB, Epperly SP and others (2005) A population model to estimate recovery time, population size, and management impacts on Kemp's ridley sea turtles. Chelonian Conserv Biol 4:767-773

Herbst LH (1994) Fibropapillomatosis of marine turtles. Annu Rev Fish Dis 4:389-425

Herbst LH, Jacobson ER, Moretti R, Brown T, Sundberg JP, Klein PA (1995) Experimental transmission of green turtle fibropapillomatosis using cell-free tumor extracts. Dis Aquat Org 22:1-12

Higgins BM, Robertson BA, Williams TD (1997) Manual for mass wire tagging of hatchling sea turtles and the detection of internal wire tags. NOAA Tech Memo NMFSSEFC-402:66

> Hilterman ML, Goverse E (2007) Nesting and nest success of the leatherback turtle (Dermochelys coriacea) in Suriname, 1999-2005. Chelonian Conserv Biol 6:87-100

Hutchinson J, Simmonds M (1991) A review of the effects of pollution on marine turtles. Greenpeace, London

Hutchinson J, Simmonds M (1992) Escalation of threats to marine turtles. Oryx 26:95-102

Hykle D (1999) International conservation treaties. In: Eckert KL, Bjorndal KA, Abreu-Grobois FA, Donnelly M (eds) Research and management techniques for the conservation of sea turtles. IUCN/Species Survival Commission Marine Turtle Specialist Group Publ No. 4, Blanchard, PA, p 228-231

> Ikonomopoulou MP, Olszowy H, Hodge M, Bradley AJ (2009) The effect of organochlorines and heavy metals on sex steroid-binding proteins in vitro in the plasma of nesting green turtles, Chelonia mydas. J Comp Physiol B 179:653-662

IUCN (1995) A global strategy for the conservation of marine turtles. IUCN Marine Turtle Specialist Group, Gland

> Jackson JBC, Kirby MX, Berger WH, Bjorndal KA and others (2001) Historical overfishing and the recent collapse of coastal ecosystems. Science 293:629-638

> Jacobson ER, Mansell JL, Sundberg JP, Hajjar L and others (1989) Cutaneous fibropapillomas of green turtles (Chelonia mydas). J Comp Pathol 101:39-52

James MC, Myers RA, Ottensmeyer CA (2005a) Behaviour of leatherback sea turtles, Dermochelys coriacea, during the migratory cycle. Proc R Soc Lond B Biol Sci 272: $1547-1555$

> James MC, Ottensmeyer CA, Myers RA (2005b) Identification of high-use habitat and threats to leatherback sea turtles in northern waters: new directions for conservation. Ecol Lett 8:195-201

Jenkins LD (2002) The science and policy behind proposed sea turtle conservation measures. Endang Species Update 19:35-40

> Jentoft S (2000) Legitimacy and disappointment in fisheries management. Mar Policy 24:141-148

JIWLP (Journal of International Wildlife Law Policy) (2002) Special Issue: International instruments for sea turtle conservation. J Int Wildl Law Policy 5(1-2):1-210

Kamel SJ, Mrosovsky N (2004) Nest site selection in leatherbacks, Dermochelys coriacea: individual patterns and their consequences. Anim Behav 68:357-366

Kamel SJ, Mrosovsky N (2005) Repeatability of nesting preferences in the hawksbill sea turtle, Eretmochelys imbricata, and their fitness consequences. Anim Behav 70: 819-828

Kamel SJ, Mrosovsky N (2006) Deforestation: risk of sex ratio distortion in hawksbill sea turtles. Ecol Appl 16:923-931
Kasparek M, Godley BJ, Broderick AC (2001) Nesting of the green turtle, Chelonia mydas, in the Mediterranean: a review of status and conservation needs. Zool Middle East 24:45-74

> Keith DA, Akcakaya HR, Thuiller W, Midgley GF and others (2008) Predicting extinction risks under climate change: coupling stochastic population models with dynamic bioclimatic habitat models. Biol Lett 4:560-563

Keller JM, Kucklick JR, Stamper MA, Harms CA, McClellanGreen PD (2004) Associations between organochlorine contaminant concentrations and clinical health parameters in loggerhead sea turtles from North Carolina, USA. Environ Health Perspect 112:1074-1079

> Keller JM, McClellan-Green PD, Kucklick JR, Keil DE, Peden-Adams MM (2006) Effects of organochlorine contaminants on loggerhead sea turtle immunity: comparison of a correlative field study and in vitro exposure experiments. Environ Health Perspect 114:70-76

Kobayashi DR, Polovina JJ, Parker DM, Kamezaki N and others (2008) Pelagic habitat characterization of loggerhead sea turtles, Caretta caretta, in the North Pacific Ocean (1997-2006): Insights from satellite tag tracking and remotely sensed data. J Exp Mar Biol Ecol 356:96-114

Kwan D, Marsh H, Delean S (2006) Factors influencing the sustainability of customary dugong hunting by a remote indigenous community. Environ Conserv 33:164-171

Lackovich JK, Brown DR, Homer BL, Garber RL and others (1999) Association of herpesvirus with fibropapillomatosis of the green turtle Chelonia mydas and the loggerhead turtle Caretta caretta in Florida. Dis Aquat Org 37:89-97

Laist D, Coe J, O'Hara K (1999) Conservation and management of marine mammals. In: Twiss J, Reeves R (eds) Conservation and management of marine mammals. Smithsonian Institution Press, Washington, DC, p 342-366

Laurance WF, Fay JM, Parnell RJ, Sounguet GP, Formia A, Lee ME (2008) Does rainforest logging threaten marine turtles? Oryx 42:246-251

Leitch K (2000) Entanglement of marine turtles in netting: Northeast Arnhem Land, Northern Territory, Australia. WWF and the Australian Department of Environment and Heritage, Darwin

> León YM, Bjorndal KA (2002) Selective feeding in the hawksbill turtle, an important predator in coral reef ecosystems. Mar Ecol Prog Ser 245:249-258

Lewison RL, Crowder LB (2007) Putting longline bycatch of sea turtles into perspective. Conserv Biol 21:79-86

> Lewison RL, Crowder LB, Shaver DJ (2003) The impact of turtle excluder devices and fisheries closures on loggerhead and Kemp's ridley strandings in the western Gulf of Mexico. Conserv Biol 17:1089-1097

Lewison RL, Crowder LB, Read AJ, Freeman SA (2004a) Understanding impacts of fisheries bycatch on marine megafauna. Trends Ecol Evol 19:598-604

> Lewison RL, Freeman SA, Crowder LB (2004b) Quantifying the effects of fisheries on threatened species: the impact of pelagic longlines on loggerhead and leatherback sea turtles. Ecol Lett 7:221-231

> Limpus CJ (1992) Estimation of tag loss in marine turtle research. Wildl Res 19:457-469

Limpus CJ (2008a) A biological review of Australian marine turtles: loggerhead turtle (Caretta caretta), Vol 1. Queensland Environmental Protection Agency, Brisbane

Limpus CJ (2008b) A biological review of Australian marine turtles: green turtle (Chelonia mydas), Vol 2. Queensland Environmental Protection Agency, Brisbane

> Limpus CJ, Chaloupka M (1997) Nonparametric regression modelling of green sea turtle growth rates (southern Great Barrier Reef). Mar Ecol Prog Ser 149:23-34 
Limpus CJ, Nicholls N (1988) The southern oscillation regulates the annual numbers of green turtles (Chelonia mydas) breeding around northern. Aust Wildl Res 15: $157-162$

Limpus CJ, Miller JD, Parmenter CJ, Reimer D, McLachlan N, Webb R (1992) Migration of green (Chelonia mydas) and loggerhead (Caretta caretta) turtles to and from eastern Australian rookeries. Wildl Res 19:347-358

Limpus CJ, Couper PJ, Read MA (1994) The green turtle, Chelonia mydas, in Queensland: population structure in a warm temperate feeding area. Mem Queensl Mus 35:139-154

Lohmann KJ, Lohmann CMF (2003) Orientation mechanisms of hatchling loggerheads. In: Bolten AB, Witherington B (eds) Loggerhead sea turtles. Smithsonian Institution Press, Washington, DC, p 44-62

Lovich JE (1996) Possible demographic and ecologic consequences of sex ratio manipulation in turtles. Chelonian Conserv Biol 2:114-117

Luschi P, Sale A, Mencacci R, Hughes GR, Lutjeharms JRE, Papi F (2003) Current transport of leatherback sea turtles (Dermochelys coriacea) in the ocean. Proc R Soc Lond B Biol Sci 270:S129-S132

Lutcavage ME, Plotkin PT, Witherington B, Lutz PL (1997) Human impacts on sea turtle survival. In: Lutz P, Musick J (eds) The biology of sea turtles. CRC Press, Boca Raton, FL, p 387-410

Lutz PL, Dunbar-Cooper A (1987) Variations in the blood chemistry of the loggerhead sea turtle, Caretta caretta. Fish Bull 85:37-43

Maffucci F, Caurant F, Bustamante P, Bentivegna F (2005) Trace element $(\mathrm{Cd}, \mathrm{Cu}, \mathrm{Hg}, \mathrm{Se}, \mathrm{Zn})$ accumulation and tissue distribution in loggerhead turtles (Caretta caretta) from the western Mediterranean Sea (southern Italy). Chemosphere 58:535-542

Marcovaldi MA, Godfrey MH, Mrosovsky N (1997) Estimating sex ratios of loggerhead turtles in Brazil from pivotal incubation durations. Can J Zool 75:755-770

Marcovaldi MA, Gallo BG, Lima EHSM, Godfrey MH (2001) Nem tudo que cai na rede é peixe: an environmental education initiative to reduce mortality of marine turtles caught in artisanal fishing nets in Brazil. In: Mann Borgese E, Chircop A, McConnell M (eds) Ocean Yearbook 15. University of Chicago Press, Chicago, IL, p 246-256

Marcovaldi M, Patiri V, Thomé J (2005) Projeto Tamar-Ibama: twenty-five years protecting Brazilian sea turtles through a community-based conservation programme. Marit Stud (MAST) 4:39-62

Margavio AV, Forsyth C (1996) Caught in the net: the conflict between shrimpers and conservationists. Texas A\&M University Press, College Station, TX

Margavio AV, Laska S, Mason J, Forsyth C (1993) Captives of conflict - the TEDs case. Soc Nat Resour 6:273-290

Marshall NA (2007) Can policy perception influence social resilience to policy change? Fish Res 86:216-227

Mast RB, Hutchinson BJ, Pilcher NJ (2004) IUCN/Species Survival Commission Marine Turtle Specialist Group news first quarter 2004. Mar Turtle Newsl 104:21-22

Mast RB, Hutchinson BJ, Howgate E, Pilcher NJ (2005) IUCN/SSC Marine Turtle Specialist Group hosts the second Burning Issues Assessment Workshop. Mar Turtle Newsl 110:13

Mast R, Seminoff J, Hutchinson B, Pilcher N (2006) The role of IUCN Marine Turtle Specialist Group in setting priorities for sea turtle conservation. Mar Turtle Newsl 113:16-18

> McCauley SJ, Bjorndal KA (1999) Conservation implications of dietary dilution from debris ingestion: sublethal effects in post-hatchling loggerhead sea turtles. Conserv Biol 13:925-929

McClellan CM, Read AJ (2007) Complexity and variation in loggerhead sea turtle life history. Biol Lett 3:592-594

McMahon CR, Hays GC (2006) Thermal niche, large-scale movements and implications of climate change for a critically endangered marine vertebrate. Glob Change Biol 12:1330-1338

Meletis ZA, Campbell LM (2007) Call it consumption! Reconceptualizing ecotourism as consumption and consumptive. Geography Compass 1:850-870

Meletis ZA, Campbell LM (2009) Benevolent and benign? Using environmental justice to explore ecotourism impacts in developing communities. Antipode 41:741-780

Meylan AB, Donnelly M (1999) Status justification for listing the hawksbill turtle (Eretmochelys imbricata) as Critically Endangered on the 1996 IUCN Red List of Threatened Animals. Chelonian Conserv Biol 3:200-224

Meylan AB, Bowen BW, Avise JC (1990) A genetic test of the natal homing versus social facilitation models for green turtle migration. Science 248:724-727

Miller JD (1985) Embryology of marine turtles. In: Gans C, Billett F, Maderson P (eds) Biology of the reptilia. John Wiley \& Sons, New York, NY, p 269-328

Miller J, Limpus C, Godfrey M (2003) Nest site selection, oviposition, eggs, development, hatching, and emergence of loggerhead sea turtles. In: Bolten A, Witherington B (eds) Loggerhead sea turtles. Smithsonian Institution Press, Washington, DC, p 125-143

- Molloy PP, McLean IB, Cote IM (2009) Effects of marine reserve age on fish populations: a global meta-analysis. J Appl Ecol 46:743-751

Monagas P, Oros J, Arana J, Gonzalez-Diaz OM (2008) Organochlorine pesticide levels in loggerhead turtles (Caretta caretta) stranded in the Canary Islands, Spain. Mar Pollut Bull 56:1949-1952

Montague CL (2008) Recovering the sand deficit from a century of dredging and jetties along Florida's Atlantic coast: a reevaluation of beach nourishment as an essential tool for ecological conservation. J Coast Res 24:899-916

> Monzón-Argüello C, Rico C, Carreras C, Calabuig P, Marco A, Lopez-Jurado LF (2009) Variation in spatial distribution of juvenile loggerhead turtles in the eastern Atlantic and western Mediterranean Sea. J Exp Mar Biol Ecol 373: 79-86

> Moore CJ (2008) Synthetic polymers in the marine environment: a rapidly increasing, long-term threat. Environ Res 108:131-139

> Moran KL, Bjorndal KA (2005) Simulated green turtle grazing affects structure and productivity of seagrass pastures. Mar Ecol Prog Ser 305:235-247

Moran KL, Bjorndal KA (2007) Simulated green turtle grazing affects nutrient composition of the seagrass Thalassia testudinum. Mar Biol 150:1083-1092

Moritz C (1994) Defining 'evolutionarily significant units' for conservation. Trends Ecol Evol 9:373-375

Mortimer JA (1984) Marine turtles in the Republic of Seychelles: status and management. IUCN Conservation Library, Gland

> Mortimer JA (1990) The influence of beach sand characteristics on the nesting behavior and clutch survival of green turtles (Chelonia mydas). Copeia 802-817

Mortimer JA, Bresson R (1994) The hawksbill nesting population at Cousin Island, Republic of Seychelles: 1971-72 to 1991-92 In: Schroeder BA, Witherington BE (eds) Proceedings of the 13th Annual Symposium on Sea Turtle Biology and Conservation. NOAA Tech Memo NMFSSEFSC 341:115-118 
Mortimer J, Donnelly M (2008) Marine turtle specialist group 2007 IUCN Red List status assessment hawksbill turtle (Eretmochelys imbricata). IUCN, Marine Turtle Specialist Group, Gland

Mrosovsky N (1997a) A general strategy for conservation through use of sea turtles. J Sustainable Use 1:42-46

$>$ Mrosovsky N (1997b) IUCN's credibility critically endangered - Commentary. Nature 389:436

Mrosovsky N (2000) Sustainable use of hawksbill turtles: contemporary issues in conservation. Key Centre for Tropical Wildlife Management, Charles Darwin University, Darwin

Mrosovsky N, Dutton PH, Whitmore CP (1984) Sex ratios of two species of sea turtle nesting in Suriname. Can J Zool 62:2227-2239

Mrosovsky N, Kamel S, Rees AF, Margaritoulis D (2002) Pivotal temperature for loggerhead turtles (Caretta caretta) from Kyparissia Bay, Greece. Can J Zool 80:2118-2124

Mrosovsky N, Ryan GD, James MC (2009) Leatherback turtles: the menace of plastic. Mar Pollut Bull 58:287-289

Musick J, Limpus C (1997) Habitat utilization and migration in juvenile sea turtles. In: Lutz P, Musick J (eds) The biology of sea turtles. CRC Press, Boca Raton, FL, p 137-163

Nichols WJ, Resendiz A, Seminoff JA, Resendiz B (2000) Transpacific migration of a loggerhead turtle monitored by satellite telemetry. Bull Mar Sci 67:937-947

Nicholson E, Mace GM, Armsworth PR, Atkinson G and others (2009) Priority research areas for ecosystem services in a changing world. J Appl Ecol 46:1139-1144

Nietschmann B, Nietschmann J (1981) Good dugong, bad dugong — bad turtle, good turtle. Nat Hist 90:54

> Norton TM, Jacobson ER, Sundberg JP (1990) Cutaneous fibropapillomas and renal myxofibroma in a green turtle, Chelonia mydas. J Wildl Dis 26:265-270

Owens DW, Hendrickson JR, Lance V, Callard IP (1978) A technique for determining sex of immature Chelonia mydas using radioimmunoassay. Herpetologica 34: 270-273

Pandolfi JM, Bradbury RH, Sala E, Hughes TP and others (2003) Global trajectories of the long-term decline of coral reef ecosystems. Science 301:955-958

Pauly D, Christensen V, Dalsgaard J, Froese R, Torres F (1998) Fishing down marine food webs. Science 279: 860-863

Peckham S, Maldonado DD, Walli A, Ruiz G, Crowder L, Nichols W (2007) Small-scale fisheries bycatch jeopardizes endangered Pacific loggerhead turtles. PLoS ONE 2(10):e1041

Pfaller JB, Limpus CJ, Bjorndal KA (2009) Nest site selection in individual loggerhead turtles and consequences for doomed-egg relocation. Conserv Biol 23:72-80

Pike DA, Stiner JC (2007) Sea turtle species vary in their susceptibility to tropical cyclones. Oecologia 153:471-478

Pikitch EK, Santora C, Babcock EA, Bakun A and others (2004) Ecosystem-based fishery management. Science 305:346-347

Pitcher TJ (2001) Fisheries managed to rebuild ecosystems? Reconstructing the past to salvage the future. Ecol Appl 11:601-617

Plotkin P (2003) Adult migrations and habitat use. In: Lutz P, Musick J, Wyneken J (eds) The biology of sea turtles, Vol II. CRC Press, Boca Raton, FL, p 225-241

Poloczanska E, Limpus CJ, Hays G (2009) Vulnerability of marine turtles to climate change. Adv Mar Biol 56:1-61

Polovina JJ, Kobayashi DR, Parker DM, Seki MP, Balazs GH (2000) Turtles on the edge: movement of loggerhead turtles (Caretta caretta) along oceanic fronts, spanning longline fishing grounds in the central North Pacific, $1997-$ 1998. Fish Oceanogr 9:71-82
Polovina JJ, Howell E, Kobayashi DR, Seki MP (2001) The transition zone chlorophyll front, a dynamic global feature defining migration and forage habitat for marine resources. Prog Oceanogr 49:469-483

$>$ Polovina JJ, Balazs GH, Howell EA, Parker DM, Seki MP, Dutton PH (2004) Forage and migration habitat of loggerhead (Caretta caretta) and olive ridley (Lepidochelys olivacea) sea turtles in the central North Pacific Ocean. Fish Oceanogr 13:36-51

Polovina J, Uchida I, Balazs G, Howell EA, Parker D, Dutton P (2006) The Kuroshio Extension Bifurcation Region: a pelagic hotspot for juvenile loggerhead sea turtles. DeepSea Res II 53:326-339

> Preen AR (1996) Infaunal mining: a novel foraging method of loggerhead turtles. J Herpetol 30:94-96

> Pretty J, Smith D (2004) Social capital in biodiversity conservation and management. Conserv Biol 18:631-638

Quackenbush SL, Casey RN, Murcek RJ, Paul TA and others (2001) Quantitative analysis of herpesvirus sequences from normal tissue and fibropapillomas of marine turtles with real-time PCR. Virology 287:105-111

> Raustiala K (1997) States, NGOs and International Environment Institutions. Int Stud Q 41:719-740

Reich KJ, Bjorndal KA, Bolten AB (2007) The 'lost years' of green turtles: using stable isotopes to study cryptic lifestages. Biol Lett 3:712-714

Reich KJ, Bjorndal KA, Frick MG, Witherington BE, Johnson C, Bolten AB (2010) Polymodal foraging in adult female loggerheads (Caretta caretta). Mar Biol 157:113-121

- Revelles M, Isern-Fontanet J, Cardona L, San Félix M, Carreras C, Aguilar A (2007) Mesoscale eddies, surface circulation and the scale of habitat selection by immature loggerhead sea turtles. J Exp Mar Biol Ecol 347: 41-57

Richardson JI (1999) Priorities for studies of reproduction and nest biology. In: Eckert K, Bjorndal KA, Abreu-Gorbois A, Donnelly M (eds) Research and management techniques for the conservation of sea turtles. IUCN Species Survival Commission, Marine Turtle Specialist Group, Publication No. 4, Blanchard, PA, p 9-12

> Richardson AJ, Bakun A, Hays GC, Gibbons MJ (2009) The jellyfish joyride: causes, consequences and management responses to a more gelatinous future. Trends Ecol Evol 24:312-322

> Rivalan P, Godfrey MH, Prévot-Julliard AC, Girondot M (2005a) Maximum likelihood estimates of tag loss in leatherback sea turtles. J Wildl Manag 69:540-548

> Rivalan P, Prevot-Julliard AC, Choquet R, Pradel R, Jacquemin B, Girondot M (2005b) Trade-off between current reproductive effort and delay to next reproduction in the leatherback sea turtle. Oecologia 145:564-574

> Robinson RA, Crick HQP, Learmonth JA, Maclean IMD and others (2009) Travelling through a warming world: climate change and migratory species. Endang Species Res 7: 87-99

Rogers RW (1989) The influence of sea turtles on the terrestrial vegetation of Heron Island Great Barrier Reef Queensland Australia. Proc R Soc Queensl 100:67-70

Ruckelshaus M, Hartway C, Kareiva P (1997) Assessing the data requirements of spatially explicit dispersal models. Conserv Biol 11:1298-1306

Rumbold D, Davis P, Perretta C (2001) Estimating the effect of beach nourishment on Caretta caretta (loggerhead sea turtle) nesting. Restor Ecol 9:304-310

Saba VS, Spotila JR, Chavez FP, Musick JA (2008) Bottom-up and climatic forcing on the worldwide population of leatherback turtles. Ecology 89:1414-1427 
Sales G, Giffoni BB, Barata PCR (2008) Incidental catch of sea turtles by the Brazilian pelagic longline fishery. J Mar Biol Assoc UK 88:853-864

Salmon M, Reiners R, Lavin C, Wyneken J (1995) Behavior of loggerhead sea turtles on an urban beach. 1. Correlates of nest placement. J Herpetol 29:560-567

Salmon M, Witherington BE, Elvidge CD (2000) Artificial lighting and the recovery of sea turtles. In: Pilcher N, Ismail G (eds) Sea turtles of the Indo-Pacific: research, management and conservation. ASEAN Academic Press, London, p 25-34

Santana Garcon J, Grech A, Moloney J, Hamann M (2010) Relative exposure index: an important factor in sea turtle nesting distribution. Aquat Conserv: Mar Freshw Ecosyst 20:140-149

Santora C (2003) Management of turtle bycatch: Can endangered species be protected while minimizing socioeconomic impacts? Coast Manag 31:423-434

Santoro M, Meneses A (2007) Haematology and plasma chemistry of breeding olive ridley sea turtles (Lepidochelys olivacea). Vet Rec 161:818-819

Santos MA, Bolten AB, Martins HR, Riewald B, Bjorndal KA (2007) Air-breathing visitors to seamounts. Section B: sea turtles. In: Pitcher TJ, Morato T, Hart PJB, Clark MR, Haggan N, Santos RS, (eds) Seamounts: ecology, fisheries and conservation. Blackwell, London, p 239-244

Sasso CR, Epperly SP (2006) Seasonal sea turtle mortality risk from forced submergence in bottom trawls. Fish Res 81: $86-88$

Sasso CR, Epperly SP (2007) Survival of pelagic juvenile loggerhead turtles in the open ocean. J Wildl Manag 71: 1830-1835

Schmid JL, Addison DS, Donnelly MA, Shirley MA, Wibbels T (2008) The effect of Australian pine (Casuarina equisetifolia) removal on loggerhead sea turtle (Caretta caretta) incubation temperatures on Keewaydin Island, Florida. J Coast Res 55:214-220

Seminoff JA, Shanker K (2008) Marine turtles and IUCN red listing: a review of the process, the pitfalls, and novel assessment approaches. J Exp Mar Biol Ecol 356:52-68

Seminoff JA, Resendiz A, Nichols WJ (2002) Home range of green turtles Chelonia mydas at a coastal foraging area in the Gulf of California, Mexico. Mar Ecol Prog Ser 242: 253-265

Seney EE, Musick JA (2007) Historical diet analysis of loggerhead sea turtles (Caretta caretta) in Virginia. Copeia 2007:478-489

Shanker K, Ramadevi J, Choudhury BC, Singh L, Aggarwal RK (2004) Phylogeography of olive ridley turtles (Lepidochelys olivacea) on the east coast of India: implications for conservation theory. Mol Ecol 13:1899-1909

Shillinger GL, Palacios DM, Bailey H, Bograd SJ and others (2008) Persistent leatherback turtle migrations present opportunities for conservation. PLoS Biol 6:e171

Smith G, Coates C (1938) Fibro-epithelial growths of the skin in large marine turtles Chelonia mydas (Linnaeus). Zoologica 23:93-98

Snover ML (2002) Growth and ontogeny of sea turtles using skeletonochronology: methods, validation and application to conservation. PhD thesis, Duke University, Durham, NC

Snover ML, Hohn AA, Crowder LB, Heppell SS (2007) Age and growth in Kemp's ridley sea turtles. In: Plotkin PT (ed) Biology and conservation of ridley sea turtles. Johns Hopkins University Press, Baltimore, MD, p 89-105

Soykan CU, Moore JE, Zydelis R, Crowder LB, Safina C, Lewison RL (2008) Why study bycatch? An introduction to the Theme Section on fisheries bycatch. Endang Species Res 5:91-102

Standora EA, Spotila JR (1985) Temperature dependent sex determination in sea turtles. Copeia 711-722

Stoker C, Rey F, Rodriguez H, Ramos JG and others (2003) Sex reversal effects on Caiman latirostris exposed to environmentally relevant doses of the xenoestrogen bisphenol A. Gen Comp Endocrinol 133:287-296

Sutherland WJ, Woodroof HJ (2009) The need for environmental horizon scanning. Trends Ecol Evol 24:523-527

> Sutherland WJ, Pullin AS, Dolman PM, Knight TM (2004) The need for evidence-based conservation. Trends Ecol Evol 19:305-308

Sutherland WJ, Armstrong-Brown S, Armsworth PR, Brereton $\mathrm{T}$ and others (2006) The identification of 100 ecological questions of high policy relevance in the UK. J Appl Ecol 43:617-627

> Sutherland WJ, Bailey MJ, Bainbridge IP, Brereton T and others (2008) Future novel threats and opportunities facing UK biodiversity identified by horizon scanning. J Appl Ecol 45:821-833

Sutherland WJ, Adams WM, Aronson RB, Aveling R and others (2009) One hundred questions of importance to the conservation of global biological diversity. Conserv Biol 23:557-567

Thiriet D (2007) Out of the 'too hard basket' - traditional hunting and animal welfare. Environ Planning Law J 24:59-73

> Tisdell C, Wilson C (2005a) Do open-cycle hatcheries relying on tourism conserve sea turtles? Sri Lankan developments and economic-ecological considerations. Environ Manag 35:441-452

Tisdell C, Wilson C (2005b) Does tourism contribute to sea turtle conservation? Is the flagship status of turtles advantageous? Marit Stud (MAST) 3/4:145-167

Tisdell C, Nantha HS, Wilson C (2007) Conservation and use of the hawksbill turtle - public valuation and attitudes: an Australian case study. Pac Conserv Biol 13:35-46

> Tomás J, Guitart R, Mateo R, Raga JA (2002) Marine debris ingestion in loggerhead sea turtles, Caretta caretta, from the western Mediterranean. Mar Pollut Bull 44:211-216

Troëng S, Chaloupka M (2007) Variation in adult annual survival probability and remigration intervals of sea turtles. Mar Biol 151:1721-1730

Tucker AD (2010) Nest site fidelity and clutch frequency of loggerhead turtles are better elucidated by satellite telemetry than by nocturnal tagging efforts: implications for stock estimation. J Exp Mar Biol Ecol 383:48-55

Watling L, Norse EA (1998) Disturbance of the seabed by mobile fishing gear: a comparison to forest clearcutting. Conserv Biol 12:1180-1197

Weishampel JF, Bagley DA, Ehrhart LM (2004) Earlier nesting by loggerhead sea turtles following sea surface warming. Global Change Biol 10:1424-1427

Wetherall JA, Balazs GH, Tokunaga RA, Yong MYY (1993) Bycatch of marine turtles in North Pacific high-seas driftnet fisheries and impacts on the stocks. Int North Pac Fish Comm Bull 53(3):519-538

Wetterer JK, Wood LD, Johnson C, Krahe H, Fitchett S (2007) Predaceous ants, beach replenishment, and nest placement by sea turtles. Environ Entomol 36:1084-1091

Whitmore CP, Dutton PH (1985) Infertility, embryonic mortality and nest site selection in leatherback and green sea turtles in Suriname. Biol Conserv 34:251-272

Wibbels T (2003) Critical approaches to sex determination in sea turtles. In: Lutz P, Musick J, Wyneken J (eds) The biology of sea turtles, Vol II. CRC Press, Boca Raton, FL, p 103-134 
Wilson C, Tisdell C (2001) Sea turtles as a non-consumptive tourism resource especially in Australia. Tour Manag 22: 279-288

Witherington BE, Martin RE (1996) Understanding, assessing, and resolving light pollution problems on sea turtle nesting beaches. FMRI Tech Rep TR-2. Florida Marine Research Institute, St. Petersburg, FL

Witt MJ, Broderick AC, Coyne MS, Formia A and others (2008) Satellite tracking highlights difficulties in the design of effective protected areas for Critically Endangered leatherback turtles Dermochelys coriacea during the inter-nesting period. Oryx 42:296-300

Witt MJ, Hawkes LA, Godfrey MH, Godley BJ, Broderick AC (2010) Predicting the impacts of climate change on a globally distributed species: the case of the loggerhead turtle. J Exp Biol 213:901-911

Witzell WN (1999) Distribution and relative abundance of sea turtles caught incidentally by the US pelagic longline fleet in the western North Atlantic Ocean, 1992-1995. Fish Bull 97:200-211

Work TM, Balazs GH (2002) Necropsy findings in sea turtles taken as bycatch in the North Pacific longline fishery. Fish Bull 100:876-880

Work TM, Raskin RE, Balazs GH, Whittaker SD (1998) Morphologic and cytochemical characteristics of blood cells from Hawaiian green turtles. Am J Vet Res 59:1252-1257

Work TM, Rameyer RA, Balazs GH, Cray C, Chang SP (2001) Immune status of free-ranging green turtles with fibropapillomatosis from Hawaii. J Wildl Dis 37:574-581

Work TM, Balazs GH, Rameyer RA, Morris RA (2004) Retrospective pathology survey of green turtles Chelonia mydas with fibropapillomatosis in the Hawaiian Islands, 1993-2003. Dis Aquat Org 62:163-176

> Work TM, Balazs GH, Schumacher JL, Marie A (2005) Epizootiology of spirorchiid infection in green turtles (Chelonia mydas) in Hawaii. J Parasitol 91:871-876

Editorial responsibility: Rory Wilson,

Swansea, UK
Work TM, Dagenais J, Balazs GH, Schumacher J and others (2009) In vitro biology of fibropapilloma-associated turtle herpesvirus and host cells in Hawaiian green turtles (Chelonia mydas). J Gen Virol 90:1943-1950

Wright B, Mohanty B (2006) Operation Kachhapa: an NGO initiative for sea turtle conservation in Orissa. In: Shanker $\mathrm{K}$, Choudhury B (eds) Marine turtles of the Indian subcontinent. University Press, Hyderabad, p 290-302

Wyneken J, Crowder L, Epperly S (2003) Evaluating multiple stressors in loggerhead sea turtles: developing a 2-sex spatially explicit model. Report NFFN7020-3-00205, National Marine Fisheries Service, Southeast Fisheries Science Center, Miami, FL

- Wyneken J, Epperly SP, Crowder LB, Vaughan J, Esper KB (2007) Determining sex in posthatchling loggerhead sea turtles using multiple gonadal and accessory duct characteristics. Herpetologica 63:19-30

Yntema C, Mrosovsky N (1980) Sexual differentiation in hatchling loggerheads (Caretta caretta) incubated at different controlled temperatures. Herpetologica 36:33-36

Zbinden JA, Davy C, Margaritoulis D, Arlettaz R (2007) Large spatial variation and female bias in the estimated sex ratio of loggerhead sea turtle hatchlings of a Mediterranean rookery. Endang Species Res 3:305-312

Zug GR, Balazs GH, Wetherall JA (1995) Growth in juvenile loggerhead seaturtles (Caretta caretta) in the north Pacific pelagic habitat. Copeia 1995:484-487

Zug GR, Balazs GH, Wetherall JA, Parker DM, Murakawa SKK (2001) Age and growth of Hawaiian green seaturtles (Chelonia mydas): an analysis based on skeletochronology. Fish Bull 100:117-127

Zurita GJC, Herrera PR, Prezas HB, Miranda GJL (1994) Living tags in three species of sea turtle hatchlings in the Mexican Caribbean. In: Schroeder B, Witherington B (eds) Proc 13th Ann Symp Sea Turtle Biology and Conservation. NOAA Tech Mem NMFS-SEFSC-341, p 273-277

Submitted: November 27, 2009; Accepted: March 9, 2010

Proofs received from author(s): May 17, 2010 